\title{
The role of E. maritimum (L.) in the dune pollination network of the Balearic Islands
}

\author{
Ivan Cortes ${ }^{1}$, Marcello Cerrato ${ }^{1}$, Arnau Ribas $^{1}$, Xavier Canyelles $^{1}$, and Lorenzo Gil ${ }^{1}$ \\ ${ }^{1}$ University of the Balearic Islands
}

March 2, 2022

\begin{abstract}
Eryngium maritimum L. (Apiaceae) is a geophyte that inhabits in the dunes of the Mediterranean and Atlantic. In Northern Europe, it is considered a highly endangered species due to reproductive problems, while in the Mediterranean, populations are in a good state of conservation. Although it is a highly entomophilous species, there is little literature on its pollinators. The aim of this study is to analyse the role played by E. maritimum in the dune pollination network of the Balearic Islands. For this purpose, two populations located in the North and South of Mallorca were chosen, in which diurnal transects were carried out to observe and capture pollinators on 15 plant species during the anthesis period of E. maritimum. In parallel, an analysis of the flowering period of 10 of these plant species was carried out to identify periods of competition. A total of 82 pollinator species were found, belonging to 30 different families. Eryngium maritimum is a strongly generalist species, with a total of 46 pollinator species. Functionally, Teucrium dunense and Helichrysum stoechas are functionally the most similar species to E. maritimum. However, analysis of phenology suggests that these three species have been able to decouple their blooms to avoid competition. The present study shows that E. maritimum plays a key role in the dune pollination network, being its anthesis located at the end of the dune flowering season, when there are no functionally similar species in flower.
\end{abstract}

The role of E. maritimum (L.) in the dune pollination network of the Balearic Islands

Cortés-Fernández, Iván ${ }^{12}$; Cerrato, Marcello Dante ${ }^{1}$; Ribas-Serra, Arnau ${ }^{1}$; Canyelles Ferrà, Xavier ${ }^{1}$ \& GilVives, Lorenzo ${ }^{1}$

1-Interdisciplinary Ecology Group, Universitat de les Illes Baleares, Carretera de Valldemossa, 07122 Palma de Mallorca, Spain.

2- Email: ivancf1995@hotmail.com

\section{Abstract}

Eryngium maritimum L. (Apiaceae) is a geophyte that inhabits in the dunes of the Mediterranean and Atlantic. In Northern Europe, it is considered a highly endangered species due to reproductive problems, while in the Mediterranean, populations are in a good state of conservation. Although it is a highly entomophilous species, there is little literature on its pollinators. The aim of this study is to analyse the role played by $E$. maritimum in the dune pollination network of the Balearic Islands. For this purpose, two populations located in the North and South of Mallorca were chosen, in which diurnal transects were carried out to observe and capture pollinators on 15 plant species during the anthesis period of E. maritimum. In parallel, an analysis of the flowering period of 10 of these plant species was carried out to identify periods of competition. A total of 82 pollinator species were found, belonging to 30 different families.Eryngium maritimum is a strongly generalist species, with a total of 46 pollinator species. Functionally, Teucrium dunense andHelichrysum stoechas are functionally the most similar species toE. maritimum. However, analysis of phenology suggests that these three species have been able to decouple their blooms to avoid competition. The present study 
shows that E. maritimum plays a key role in the dune pollination network, being its anthesis located at the end of the dune flowering season, when there are no functionally similar species in flower.

\section{Keywords}

Eryngium maritimum, pollination network, dune,

connectance, resilience

\section{Introduction}

Pollination is considered one of the most crucial plant-animal interactions, influencing on dynamics and diversity of plant communities (Fantinato et al., 2018b). Widespread declines in pollinators populations had led to a concern about a global pollination crisis (Burkle et al., 2013; Tylianakis, 2013). By reducing pollinator availability and nesting sites due to habitat modifications, cross-pollination levels can be modified influencing plant fruit and seed production (Vanbergen et al., 2014; Traveset et al., 2018). At the same time, anthropization is jeopardizing the sustainability of ecosystems and the ability to resist future environmental changes (Macdougall et al., 2013). Among ecosystems, coastal habitats, such as seashores and dune ridges, are considered some of the most threatened habitats (Gigante et al., 2018), due to habitat loss (Coverdale et al., 2013), global warming (Culbertson et al., 2009) and coastal salination due to an increased sea-level (Chu-Agor et al., 2011). Concretely, coastal dune ecosystems are a hotspot for specialized pollinator species (Cane, 1991), displaying highly specialized species and networks higher risks of extinction (Aizen et al., 2012; Burkle et al., 2013). Understanding plant-pollinator interactions is vital to give light to coevolutionary processes in highly diverse communities (Bascompte \& Jordano, 2007) and to evaluate the maintenance of ecosystem's resilience over time (Fantinato et al., 2019). So, polllinators are used as a bioindicator species as the decline of their populations are strongly associated with anthropogenic influence (Biesmejer et al., 2006). At the same time, some attributes of the pollination network (selectiveness, nestedness, connectance) have an ecological meaning in the assessment of habitat resilience to various forms of disturbances (Lázaro et al., 2016; Traveset et al., 2018; Fantinato et al., 2019).

Eryngium maritimum L. is a geophyte from the Apiaceae family that inhabits in sand dunes of the Atlantic and Mediterranean coasts (Isermann \& Rooney, 2014). Although it is thought that E. maritimum is a generalist species for pollinators (Isermann \& Rooney, 2014) and strongly dependent of them due to its low rate of autocompatibility (Cortés-Fernández et al., 2021), its role in the coastal pollination network has never been assessed. In this sense, there is a lack of studies analysing the main pollinators of the species in the Balearic Islands and how the species competes with the other species of the habitat for pollinators. This is particularly important as the species is considered a highly-threatened species in Northern European populations (van der Maarel \& van der Maarel-Versluys, 1996; Aviziene et al., 2008), where it displays low fruit and seed set production, and conversely, Balearic populations exhibit high fruit and seed set (CortésFernández et al, 2021), displaying its populations good conservation status.

Eryngium maritimum is a diagnostic species of coastal dunes of the phytosociological class Ammophiletea Br.-Bl. et Tx. ex Westhoff et al. 1946 (Marcenò \& Jimenez-Alfaro, 2017). In the Balearic Islands, it develops optimally in embryonic and white dunes, where perennial grasses are not dominant (Llorens et al., 2007). The autofecundation capacity of the species is low, as well as its anemophily, which suggests that the species is strongly entomophilous (Cortes-Fernández, 2021a). It coinhabits with a great variety of plant species which are strongly pollinator-dependent, including members of the Lamiaceae (Teucrium dunense Sennen), Leguminosae (Lotus cytisoides L.), Asteraceae (Helichrysum stoechas (L.) Moench) and Papaveraceae (Glaucium flavum Crantz). The best approaches to give light to the dune pollination networks of the Balearic Islands have been carried out in a fixed dune of the North of Mallorca (Son Bosc; Tur et al., 2013; Castro-Urgal et al., 2013; Castro-Urgal \& Traveset, 2014; Traveset et al., 2017; Lázaro et al., 2020), which displays a differential floral diversity (Crucianellion maritimae Rivas Goday \& Rivas-Martinez 1963) than where E. maritimum inhabits, and Cala Mesquida (Castro-Urgal \& Traveset, 2014), the most representative study carried out in a E. maritimum habitat. Unfortunately, for this latest work no species list or network is provided, and so the role of E. maritimum in the pollination network is yet unknown. 
The main objective of the present study is to analyse E. maritimum pollinators and what is its specific role of the species in the dune pollination network of the Balearic Islands. The main hypothesis is that $E$. maritimum is a generalist species and it will play a key role in the pollination network of the habitat. This study will give light to the ecology of the species in the Balearic Islands, continuing a series of studies which analysed its reproductive biology, germination and salinity tolerance in this area (Cortés-Fernandez, 2021a, 2021b, 2022).

\section{Material and methods}

\section{Study area}

Pollinator surveys were carried out in two different coastal dunes of Mallorca (Balearic Islands, Spain), one located in the North and one in the South of the island (Figure 1). First sampling area was located in Son Serra de Marina (SS, 39.7309N, 3.2382E), in the North of the island. Although the area is relatively well-conserved compared to other areas of the island, it suffers from severe anthropogenic impact mainly due to tourist pression, overall in the drift line zone. On the other hand, the other sampling area was located in Es Trenc (ET, 39.3382N, 2.9903E), in the south of the island. The area is strictly protected, and so interacting with the dunes is completely forbidden. In each area three transects of $50 \mathrm{~m}$ were carried out, separated $100 \mathrm{~m}$ with each other, in order to increase the plant diversity available per zone. Each transect consist of a straight line of $50 \mathrm{~m}$ placed perpendicularly from the coastline. In both areas, vegetation, and so transects, followed a clear sequence from the seashore inland. The sequence starts from therophytes in the drift line zone (Aliance Cakilion maritimae), very altered by the presence of tourism, followed by embryonic dune (Agropyro-Minuartion peploidis ) and white dune communities (Ammophilion australis ), which lead to semi-fixed dunes (Crucianellion maritimae) landwards (Llorens et al., 2007).

\section{Pollinator surveys}

Areas were sampled for 10 weeks, from the beginning of E. maritimum flowering in the first week of June and finishing the second week of July, plus two weeks extra (one after and one before) in order two observe pollinator diversity variation. Surveys took place between 08:00-18:00h under favourable weather conditions.

A pollinator survey involved an observer slowly walking (40 min) a transect and recording only those insects that contacted the plant's reproductive structures while actively searching for pollen and/or nectar. Search was limited to those insects belonging to the insect orders most commonly associated with pollination (Coleoptera, Diptera, Hymenoptera and Lepidoptera). Due to the great quantity of pollinators in both areas, only first interaction per session per pollinator-plant species was recorded, in other to construct a presence-absence interaction matrix per session. Insects which were not possible to identify were netted and placed into individually-labelled vials, or captured directly into vials. To minimize our impact on local insect populations, only subsets of individuals from each non-identified species were captured. Insects were frozen and transferred to the laboratory where they were stored until identification.

\section{Pollinators behaviour}

Specific observations of E. maritimum pollinators were carried out to assess pollinators behaviour and diversity. In each subarea random individuals were selected and observations were made during 20 minutes each transect, with a total observation time of $20 * 8^{*} 4 *=640$ minutes in each area. For each interaction, the number of visited capitula, its whorl and the total time spend in an individual was recorded.

\section{Phenology}

In each sampling area plant surveys were carried out to assess the phenological distribution of plants coinhabiting with E. maritimum . Each sampling day a phenological survey was carried out in 10 key species of the habitat, in order to analyse the relationship between flowering and pollinator surveys. To do so, for each species individuals, inflorescences or flowers were followed and flowered units were counted as proposed in Gil (1994).

Network analysis 
Three pollination matrices were carried out, one for each population and one for the whole observations. Descriptors for structure and resilience of pollinator interactions were calculated as described by Fantinato et al. (2019) and Traveset et al. (2017) using the bipartite R-based package (Dormann et al., 2008). At network level, Connectance $(C)$, Nestedness $(N, N O D F)$, Specialization Index $\left(H_{2}{ }^{\prime}\right)$, Shannon diversity Index $(S)$, Links per species $(L P)$, Vulnerability $(V)$ and number of compartments $(N C)$ were calculated. Connectance is a proportion of the observed links divided by the number of total of possible links (Gomez \& Zamora, 2009). Nestedness is the ecological tendency of specialist species to interact with a subset of species that interact with more generalist species (Almeida-Neto et al., 2008; James et al., 2012). Network specialization Index (Bluthgen et al., 2006) is a measure of the network degree of selectiveness, and ranges between 0 (opportunistic, high niche overlap) and 1 (selective, high niche differentiation). Finally, number of compartments reflects the rate of clustering of the network. At species level, Species Strenght (Str ), Specificity (Spec ) and Specialization level ( $d^{\prime}$ ) were considered for analysis. Species strength is the sum of dependencies of a species (Bascompte et al., 2006). Specificity is considered as the coefficient of variation of interactions, and ranges from 0 (low specificity) to 1 (high specificity). Specialization level is, similarly, the level of selectiveness of a species. Using this metric, the degree of selectivity was established based on theSpec parameter (highly selective, Spec $>0.75$; selective, $0.75>$ Spec $>0.5$; opportunistic, $0.5>$ Spec $>$ 0.25 ; highly opportunistic, Spec $<0.25$ ), as suggested by Castro-Urgal and Traveset (2013).

For each of the three networks, total number of plant species with interactions (NP) and total number of pollinators (NS) were calculated. Generalized linear mixed effect models were used to compare areas. In order to confirm that our results described patterns that are different from random, models were compared with an appropriate null model (Dormann et al ., 2008). To do so, 1000 null versions (null model) of each community matrix were generated using the shuffle_webalgorithm implemented in the bipartite package with method r2d (Dormann et al ., 2008).

\section{Results}

\section{Pollinator surveys}

Our visual survey recorded 353 contacts, involving 82 pollinator (Table S1) and 15 plant species (Table S2). Rarefaction analysis showed that the number of new interactions per session was still growing, but decelerating, at the end of the sampling sessions (Figure S1).Diversity of pollinators and Shannon diversity Index indicated than SS was richer in pollinators than ET (Table 1), recording interactions in 16 different plant species in SS, while only 6 in ET. Connectance, Nestedness and Niche Overlap was higher in ET than in SS while Links per species and Vulnerability were lower. Compartment analysis showed that two different compartments were identified considering both populations and ET individually, while SS displayed only one compartment.

Network evaluation indicated that SS web was more complex than ET, displaying more nodes and links (Figure 2 ). In both webs, E. maritimum, T. dunense and H. stoechas displayed the higher diversity of pollinators and interactions. On the other hand, in other plant species like Ononis natrix subsp. ramosissimaDesf. , Calystegia soldanella (L.) R. Br. andLimbarda chritmoides (L.) Dumort only one pollinator species was found (Figure S2 ). Although no data about pollinator abundancy was gathered, less pollinators were observed in ET than in SS. On the other hand, the specialization index (H2) indicated that in SS pollinators were more opportunistic than in ET. However, it must be considered that observed versus randomized data suggested that data from ET is not significant enough to indicate clear patterns, contrary to SS and to the full network of both areas (Table 1 ).

Apis mellifera L. was the most opportunistic species of pollinator, visiting 10 of the 15 plant species, while 46 pollinator species were found only visiting one plant species (Figure S2 ). Of the 30 families found, Apidae , Syrphidae and Colletidae were the more diverse families in the network. On the other hand, two families (Satyridae, Bruchinidae) were represented by only one species. Hymenoptera was the most represented class in the network, followed by Diptera and Lepidoptera. Orthoptera was represented only by one interaction, carried out in P. maritimum L. and probably accidentally, as a nymph was resting on a stamen. Similarly, 
Hemiptera was represented only by one interaction, carried out by Oxycarenus lavaterae (Fabricius, 1787) in E. maritimum .

Three plant species presented very low levels of selectiveness, H. stoechas, T. dunense and E. maritimum, while $C$. soldanella, O. natrix subsp. ramossisima and L. chritmoides presented only 1 interaction and were considered as highly selective (Table S2 ). The vast majority of pollinator species in both populations were highly selective, while high-opportunistic species were proportionally negligible, representing less than $2 \%$ of species (Figure 4; Table S3 ). In ET highly selective and selective species were more representative than in SS, where selective and opportunistic species were more represented. Attending at pollinator families, most of them were classified as highly selective, being the only opportunistic families Andrenidae, Apidae, Lycaenidae, Pieridae, Scarabeidae and Syrphidae (Table S4 ). Considering pollinator orders, Coleoptera, Diptera, Hymenoptera and Lepidoptera can be considered as opportunistic (Table S5) . On the other hand, Orthoptera and Hemiptera were so unrepresented $(\mathrm{N}=1)$ that it is not possible to evaluate selectiveness.

Pollination networks strongly varied among sessions (Figure S3 ). In, first sessions E. maritimum was outside of its flowering period and T.dunense and H.stoechas gathered the vast majority of interactions. Then, T. dunense and especially H. stoechas experimented a decrease while E. maritimum began to attract more interactions. In the third session, E. maritimum was already the stronger species in terms of pollinator diversity. A slight decrease in pollinator diversity was observed comparing first and last sampling sessions in each area.

\section{Phenology}

Seven of the ten species displayed Gauss-like phenological curves, with a definite flowering peak, while $L$. cytisoides, G. flavumand E. pithyusa presented a diffuse flowering period (Figure 5 ). Considering the most abundant species in the habitat, the flowering period of E. maritimum is located afterT. dunense and $H$. stoechas, being the last species beforeP. maritimum. Observations of the flowering periods between SS an ET during pollinators samples, although not quantitatively evaluated, suggested that plant populations at ET flowered with a delay of, at least, one week respect to SS.

\section{Pollination behaviour}

A correlation between time spent in visits and the whorl order was observed, decreasing the time spent in visits in outer whorls $(D F=4, F=2.21, P=0.04)$. Time spent in visits and number of visited capitula was variable among families (Figure 6 ). Apidae pollinators visited more capitula per plant than any other family, while Lycaenidae pollinators spent more time per visits. Data about some families were insufficient to analyse behaviour deeper.

\section{Discussion}

\section{Pollinator surveys}

Most plant species are generalist rather than specialists (Herrera, 1996; Zamora, 2006), and similarly the great majority of pollinators visit a great variety of plant species (Bosch et al., 2009). Most of the species observed in the present study can be considered as specialists, as their interactions were found in one or a few plant species. However, Petanidou et al. (2008) observed than $90 \%$ of species labelled as specialist are indeed generalist when multiple-year data is added. On the other hand, as suggested by Armbruster (2006), generalist pollinators can behave as specialist species in local scale, as a consequence of ecological specialization. The evaluation of the level of specialization is particularly important as more specialized networks are more prone to collapse (Thebault \& Fontaine, 2010). Including the interactions found by pollen analysis is known to reduce the proportion of extreme specialist and increase connectance, as pollen remains in the body of pollinators for long period providing a record of visitation history rather than a single sample (Courtney et al., 1982; Bosch et al., 2009).

SS presented a higher number of visits and pollinator richness than ET, which could be related to differences in plant species richness and abundance between populations, that although were not objective of the present 
work, were observed in the field. In this sense, floral abundance and plant diversity was higher in SS, factors that have been associated with a high density and abundance of interactions (Bluthgen et al. 2007; Haegen and Kramer, 2010). On the other hand, a high pollinator richness can be considered as an indicator of moderate disturbance levels. As proposed by Connell (1978) in the intermediate disturbance hypothesis (IDH), moderate disturbances levels maintain the highest levels of species richness. In this sense, two possible scenarios emerge. In the first scenario, disturbance is higher in ET than in SS, which is located in the moderate levels, and so species richness decreases in ET. In the second scenario, disturbance in ET is lower than in SS, also presenting lower level of species richness. In sandy dune ecosystems it has been documented that human disturbance increases micro-site diversification (Slaviero et al., 2016) but, at the same time, it increases competition between pollinators and local exclusion of weaker species as a result of a reduction of floral resources availability (Wozjic et al., 2018). However, conclusions derived from IDH should be taken into consideration with caution as it is usually an oversimplification of nature (Fox, 2013).

Although connectance has been widely used as an indicator of resilience (Heleno et al., 2012), the negative relationship between species richness and connectance might be responsible of the differences in connectance between populations rather than responses to human disturbances (Olesen \& Jordano, 2002; Fantinato, 2019). Rarefaction curves indicated that more sampling effort would have conducted to a higher species richness in both populations, which would have an impact in connectance values. In this sense, new pollinator observations were carried out in close and similar populations during the study (Rigo, pers. comm.), which could be interpreted as an indicator to increase sampling effort with multiannual data. On the other hand, high values of selectiveness with low values of nestedness are associated with low levels resistence and resilience (Bastolla et al., 2009) as a result of intense disturbances (Revilla et al., 2015; Welti \& Joern, 2018), tough not always (Spiesman and Inouye 2013). In the field, more human interaction, and so high levels of disturbance, was observed in ET than in SS, although the last is not protected. So, attending to the indicators and to field observations, more conservation efforts have to be dedicated to avoid dune degradation by anthropization in ET than in SS.

Habitat changes produce different kind of responses depending on the pollinator species (Traveset et al., 2018). Solidary bees, for example, are more susceptible to habitat destruction as they present preferential food resources and nesting sites (Ferreria et al., 2015), while Coleoptera and Dipterans may be less affected as they do not need to return to their nesting sites after foraging (Parsche et al., 2011). However, little is known about how functional pollinator groups change their interaction pattern as a result of disturbances (Lazaro et al., 2016; Traveset et al., 2018). Apidae were the most representative family of pollinators, being generalist and with higher abundances. This is rational considering than bees are generally polylectic, exploiting pollen resources from various species (Minckley \& Roulston, 2006), although even oligolectic bees visit various species for nectar. In fact, bees usually alternate visits between a pollen-rich source and a nectar-rich source (Bosch et al., 2009). On the other hand, Hymenoptera was the most represented order of pollinators in the dunes, which is consistent with the observations of previous studies (Castro-Urgal \& Traveset, 2014, Fantinato et al., 2018a). Other orders, such as Diptera and Lepidoptera, also played an important role in dune pollination (Gil, 1994). While myophile pollination is known to be usually focused on species with little odourless flowers, psychophyle pollination is carried out preferentially in species with more intense aromas and big tubular flowers (Aguado Martin et al., 2015). In our study, both orders exploited floral resources of a high diversity of plant species, including E. maritimum .

An invasive plant species, Senecio cineraria DC., was found in our sampling sessions in SS. Attending to the observed interactions, it behaves as a generalist species, although one pollinator species, Halictus fulvipes , was only found exploiting its floral resources. Previous studies carried out in a very close area suggested that alien species (in this case Carpobrotus edulis (L.) L. Bolus) influence the quantitative component of pollination, influencing negatively (competition) or positively (facilitation; Moragues \& Traveset, 2005). So, the present results describe the effect of another alien species, quite abundant in the Balearic Island coasts due to its commercialization as garden plant, producing pollinator species displacements from autochthonous to allochthonous species, altering the structure of coastal networks. 


\section{Phenology}

A strong phenological variation was present among sampling sessions. For most pollinator species, flowering phenology is the main driver for pollinator distribution rather than flower traits (Bosch et al., 1997), usually presenting short activity periods of pollination (Farre-Armengol et al., 2015). However, a few species presented irregular and long phenological periods (L. cytisoides, G. flavum andE. phitysusa). While $L$. cytisoides and E. phityusaare strongly entomogamous, G. flavum presents higher levels of autocompatibility (Gil, 1994), which could be related with their irregular phenology and the low pollinator diversity observed in the species, which is particularly visited by coleoptera.

The phenological distribution of species with very low selectiveness (H. stoechas, T. dunense, E. maritimum ) suggests that there is a selective pression to decouple flowering between species as to avoid interspecific competition for pollinators. At community level, competition is thought to be the primary selective force moulding flowering schedules (Waser, 1978; Rathcke, 2014). However, when pollinator abundance is optimal, also facilitation among species can occur (Rathcke, 1983), as a sequential mutualism, in which early-flowering species support pollinators of late-flowering species (Waser \& Real, 1983), or as a result of synchronous blooms that attract more pollinators that single species alone (Rathcke, 1983). Differences in phenological timing between populations could be related with temperature, as southern coastal populations due to sea currents are colder (Guijarro, 1986; Table S7), which is known to produce a delay in flowering (Gil, 1994, Llorens et al., 2007). On the other hand, the effect of wind is known to have a great impact in pollinators, which enhances the importance of multi-annual data to reduce the potential impact of this variable. On the other hand, more focus should be put on pollinator species abundance in both areas, because attending to our observations strongly varied among sampling sessions.

\section{Pollinator behaviour}

Remarkable differences were found between families attending at pollination behaviour. Apidae, the most represented family in both populations, visited more capitula per foraging bout, spending few time per visit, which is consistent with the results of previous studies (Brunet et al., 2009). The high variability observed in the behaviour of Apidae could be attributed to the presence of different functional groups within the family (i.e. bumble-bees, solitary bees and social bees) with usually present different pollination behaviours, spending bumble-bees less time per visit but interacting with more flowers per visit (Brunet et al., 2009). The high values of time per visit observed in Lepidoptera, overall in Polyommatus celina, could be attributed to behavioural thermoregulation (Kevan \& Shorthouse, 1970), and not really to extensive periods of foraging. In this sense, it must be considered that not all insect visitors may actually be pollinators, and also that pollination is not equally probable among pollinator species, due to differences in carrying capacity, morphology, foraging behaviour and the degree of fidelity (Lindsey, 1984). For example, Coleoptera is known to visit a great variety of plant species, but at the same time is generally considered to have a low effective pollination rate (Thayer et al., 2003; Sayers et al., 2019). However, the evaluation of all these parameters in a single study is prohibitive, and so simplifications, as we did, should be carried out.

\section{The role of E. maritimum}

It can be considered as an extreme opportunistic species, presenting pollinators from a great variety of families, which visit flowers for nectar and pollen, which is consistent with previous studies carried out in northern populations (Hegi, 1935; Fitter \& Peat, 1994; Westrich, 2001; Zanella et al., 2009). Apiaceae species are known to be visited by a large quantity of insects (Davillla, 2006; Zych et al., 2019) as a result of not presenting floral restrictions accessing to pollen and nectar (Lyndsey, 2014). The species presented the greater species strength and pollinator richness in both populations. This is logical considering that the focus of the study was put on the species, and as a consequence of oversampling, the strength of E. maritimum could be overestimated, as the study comprises its whole flowering period. However, a key central role of the species can be defined considering the diversity of pollinators that exploit the floral resources of the species, in a period in which E. maritimum is the last species flowered previously to the arrival of cold temperatures. In this sense, $P$. maritimum flowers are not functionally similar, and its known to be strongly 
related to evening and nocturnal rather than diurnal pollinators (Eisikowitch \& Galil, 1971). So, it can be concluded that conservation of E. maritimum is extremely important in terms of pollination, as a vast variety of pollinators depend on the species at the end of the flowering season previously to the decrease in activity due to temperature changes (Mellanby, 1939; Taylor, 1963). Finally, considering the results of the present study, it is improbable that the decrease in fruit and seed set in northern European populations could be attributed to specific pollinator extinctions, as the species behaves as an extremely opportunistic in terms of pollination. However, as suggested by Armbruster (2006), some species can behave as a specialist locally, so replicas of this study in northern populations would be critical to evaluate a potential cause of its decrease in fitness.

\section{Conclusions}

1. Eryngium maritimum plays a key role in the pollination network

2. It is a widely generalist species

3. It flowers after the other two main generalist species,H.stoechas and T.dunense, possibly to avoid pollinator competence

4. SS pollination network is more complex than in ET

5. Hymenoptera are the main pollinators of dunes, although Diptera and Lepidoptera also play a major role

\section{Data accessibility}

Data are available from the Dryad Digital. Repository: https://doi.org/10.5061/dryad.p8cz8w9s8

\section{References}

Aguado Martin, L. O., Vinuela Sandoval, E., \& Fereres Castiel, A. (2015). Guia de campo de los polinizadores de Espana. Ediciones Paraninfo, SA.

Aizen, M. A., Sabatino, M., \& Tylianakis, J. M. (2012). Specialization and rarity predict nonrandom loss of interactions from mutualist networks. Science, 335 (6075), 1486-1489.

Almeida-Neto, M., Guimaraes, P., Guimaraes Jr, P. R., Loyola, R. D., \& Ulrich, W. (2008). A consistent metric for nestedness analysis in ecological systems: reconciling concept and measurement. Oikos , $117(8), 1227-1239$.

Armbruster, W.S. (2006). Evolutionary and ecological aspects of specialized pollination: views from the Arctic to the Tropics. In: Plant-Pollinator Interactions, from Specialization to Generalization (edsWaser, N.M. \& Ollerton, J.). University of Chicago Press, Chicago, IL, pp. 260-282

Aviziene, D., Pakalnis, R., \& Sendzikaite, J. (2008). Status of red-listed species Eryngium maritimum L. on the Lithuanian coastal dunes. In Environmental Engineering. The 7th International Conference. Vilnius: Gediminas Technical University (pp. 22-28).

Bascompte, J., Jordano, P., \& Olesen, J. M. (2006). Asymmetric coevolutionary networks facilitate biodiversity maintenance. Science , 312 (5772), 431-433.

Bascompte, J. \& Jordano, P. (2007). Plant-animal mutualistic networks: the architecture of biodiversity. Annu. Rev. Ecol. Evol. Syst., 38 , 567-593.

Bastolla, U., Fortuna, M. A., Pascual-Garcia, A., Ferrera, A., Luque, B., \& Bascompte, J. (2009). The architecture of mutualistic networks minimizes competition and increases biodiversity. Nature , 458 (7241), 1018-1020.

Biesmejer, J.C., Roberts, S.P.M., Reemer, M., Ohlemuller, R., Edwards, M., Peeters, T. et al. (2006). Parallel declines in pollinators and insect-pollinated plants in Britain and the Netherlands. Science , 313, 351-354. 
Bluthgen, N., Menzel, F., \& Bluthgen, N. (2006). Measuring specialization in species interaction networks. BMC ecology , 6 (1), 1-12.

Bluthgen, N., Menzel, F., Hovestadt, T., Fiala, B., \& Bluthgen, N. (2007). Specialization, constraints, and conflicting interests in mutualistic networks. Current biology , 17 (4), 341-346.

Bosch, J., Retana, J., \& Cerda, X. (1997). Flowering phenology, floral traits and pollinator composition in a herbaceous Mediterranean plant community. Oecologia , 109 (4), 583-591.

Bosch, J., Martin Gonzalez, A. M., Rodrigo, A., \& Navarro, D.(2009). Plant-pollinator networks: adding the pollinator's perspective. Ecology letters , 12 (5), 409-419.

Burkle, L. A., Marlin, J. C., \& Knight, T. M. (2013). Plant-pollinator interactions over 120 years: loss of species, co-occurrence, and function. Science, 339 (6127), 1611-1615.

Cane, J. H. (1991). Soils of ground-nesting bees (Hymenoptera: Apoidea): texture, moisture, cell depth and climate. Journal of the Kansas Entomological Society , 406-413.

Castro-Urgal, R., \& Traveset, A. (2014). Differences in flower visitation networks between an oceanic and a continental island. Botanical Journal of the Linnean Society , 174 (3), 478-488.

Catford, J. A., Daehler, C. C., Murphy, H. T., Sheppard, A. W., Hardesty, B. D., Westcott, D. A., ... \& Hulme, P. E. (2012). The intermediate disturbance hypothesis and plant invasions: Implications for species richness and management. Perspectives in Plant Ecology, Evolution and Systematics , 14 (3), 231-241.

Chu-Agor, M. L., Munoz-Carpena, R., Kiker, G., Emanuelsson, A., \& Linkov, I. (2011). Exploring vulnerability of coastal habitats to sea level rise through global sensitivity and uncertainty analyses. Environmental Modelling \& Software, 26 (5), 593-604.

Connell, J. H. (1978). Diversity in tropical rain forests and coral reefs. Science, 199 (4335), 1302-1310.

Courtney, S. P., Hill, C. J., \& Westerman, A. (1982). Pollen carried for long periods by butterflies. Oikos , 260-263.

Coverdale, T. C., Herrmann, N. C., Altieri, A. H., \& Bertness, M. D. (2013). Latent impacts: the role of historical human activity in coastal habitat loss. Frontiers in Ecology and the Environment , 11 (2), 69-74.

Culbertson, J., Dennison, W. C., Fulweiler, R. W., Hughes, T., Kinney, E. L., Marba, N., ... \& Valiela, I. (2009). Global loss of coastal habitats: Rates, causes and consequences . C. M. Duarte (Ed.). Madrid, Spain: Fundacion BBVA.

Davila, Y. C. (2006). Pollination ecology of Trachymene incisa (Apiaceae): understanding generalised plant-pollinator systems.

Dormann, C. F., Gruber, B., \& Frund, J. (2008). Introducing the bipartite package: analysing ecological networks. interaction , 1 (0.2413793).

Eisikowitch, D., \& Galil, J. (1971). Effect of wind on the pollination of Pancratium maritimum L. (Amaryllidaceae) by hawkmoths (Lepidoptera: Sphingidae). The Journal of Animal Ecology ,673-678.

Fantinato, E., Del Vecchio, S., Silan, G., Buffa, G., (2018a). Pollination networks along the sea-inland gradient reveal landscape patterns of keystone plant species. Sci. Rep.

$8,1-9$.

Fantinato, E., Del Vecchio, S., Giovanetti, M., Acosta, A. T. R., \& Buffa, G. (2018b). New insights into plants co-existence in species-rich communities: The pollination interaction perspective. Journal of Vegetation Science, 29 (1), 6-14. 
Fantinato, E., Del Vecchio, S., \& Buffa, G. (2019). The co-occurrence of different grassland communities increases the stability of pollination networks. Flora, 255, 11-17.

Farre-Armengol, G., Filella, I., Llusia, J., \& Penuelas, J.(2015). Relationships among floral VOC emissions, floral rewards and visits of pollinators in five plant species of a Mediterranean shrubland. Plant ecology and evolution, 148 (1), 90-99.

Fitter, A. H., \& Peat, H. J. (1994). The ecological flora database. Journal of Ecology , 415-425.

Fox, J. W. (2013). The intermediate disturbance hypothesis should be abandoned. Trends in ecology $\mathscr{E}$ evolution, 28 (2), 86-92.

Gigante, D., Acosta, A. T. R., Agrillo, E., Armiraglio, S., Assini, S., Attorre, F., .. \& Viciani, D. (2018). Habitat conservation in Italy: the state of the art in the light of the first European Red List of Terrestrial and Freshwater Habitats. Rendiconti lincei. Scienze fisiche e naturali , 29 (2), 251-265.

Guijarro, J. A. (1986). Contribucion a la bioclimatologia de Baleares.

Gil, L. (1994). Biologia reproductiva de la flora litoral de Baleares. I. Dunas y roquedos maritimos. Unpublished. Ph. D. thesis, University of the Balearic Islands, Balearic Islands, Spain .

Hegi, G. (1935). Illustrierte Flora von Mittel-Europa: mit Besonderer Berucksichtigung von Deutschland, Osterreich und der Schweiz: zum Gebrauche in den Schulen und zum Selbstunterricht. Bd. 5. T. 3.

Heleno, R., Devoto, M., \& Pocock, M. (2012). Connectance of species interaction networks and conservation value: is it any good to be well connected?. Ecological indicators , 14 (1), 7-10.

Herrera, C.M. (1996). Floral traits and plant adaptation to insect pollinators: a devil's advocate approach. In: Floral Biology, Studies on Floral Evolution in Animal-pollinated Plants (eds Lloyd, D.G.\& Barrett, S.C.H.). Chapman \& Hall, New York, pp. 65-87.

James, A., Pitchford, J. W., \& Plank, M. J. (2012). Disentangling nestedness from models of ecological complexity. Nature , 487 (7406), 227-230.

Kevan, P. G., \& Shorthouse, J. D. (1970). Behavioural thermoregulation by high arctic butterflies. Arctic , 268-279.

Lazaro, A., Tscheulin, T., Devalez, J., Nakas, G., Stefanaki, A., Hanlidou, E., \& Petanidou, T. (2016). Moderation is best: effects of grazing intensity on plant-flower visitor networks in Mediterranean communities. Ecological Applications , 26 (3), 796-807.

Lazaro, A., Gomez-Martinez, C., Alomar, D., Gonzalez-Estevez, M. A., \& Traveset, A. (2020). Linking species-level network metrics to flower traits and plant fitness. Journal of Ecology , 108 (4), 12871298.

Lindsey, A. H. (1984). Reproductive biology of Apiaceae. I. Floral visitors to Thaspium and Zizia and their importance in pollination. American Journal of Botany, 71 (3), 375-387.

MacDougall, A. S., McCann, K. S., Gellner, G., \& Turkington, R. (2013). Diversity loss with persistent human disturbance increases vulnerability to ecosystem collapse. Nature , 494 (7435), 86-89.

Marceno, C., \& Jimenez-Alfaro, B. (2017). The Mediterranean Ammophiletea Database: a comprehensive dataset of coastal dune vegetation. Phytocoenologia , 47 (1), 95-105.

Mellanby, K. (1939). Low temperature and insect activity. Proceedings of the Royal Society of London. Series B-Biological Sciences , 127 (849), 473-487.

Minckley, R.L. \& Roulston, T.H. (2006). Incidental mutualisms and pollen specialization among bees. In: Plant-Pollinator Interactions, from Specialization to Generalization (edsWaser, N. M. \& Ollerton, J.). University of Chicago Press, Chicago, pp. 69-98. 
Moragues, E., \& Traveset, A. (2005). Effect of Carpobrotus spp. on the pollination success of native plant species of the Balearic Islands. Biological Conservation, 122 (4), 611-619.

Olesen, J. M., \& Jordano, P. (2002). Geographic patterns in plant-pollinator mutualistic networks. Ecology, 83 (9), 2416-2424.

Parsche, S., Frund, J., \& Tscharntke, T. (2011). Experimental environmental change and mutualistic vs. antagonistic plant flower-visitor interactions. Perspectives in Plant Ecology, Evolution and Systematics , 13 (1), 27-35.

Petanidou, T. \& Potts, S.G. (2006). Mutual use of resources in Mediterranean plant-pollinator communities: How specialized are pollination webs? In: Plant-Pollinator Interactions, from Specialization to Generalization (eds Waser, N. M. \& Ollerton, J.). University of Chicago Press, Chicago, IL, pp. 221-244.

Petanidou, T., Kallimanis, A. S., Tzanopoulos, J., Sgardelis, S. P., \& Pantis, J. D. (2008). Long-term observation of a pollination network: fluctuation in species and interactions, relative invariance of network structure and implications for estimates of specialization. Ecology letters , 11 (6), 564-575.

Rathcke, B. (1983). Competition and facilitation among plants for pollination. Pollination biology , 305 , 329 .

Rathcke, B. J. (2014). 22. Patterns of Flowering Phenologies: Testability and Causal Inference Using a Random Model. In Ecological Communities (pp. 383-394). Princeton University Press.

Revilla, T. A., Encinas-Viso, F., \& Loreau, M. (2015). Robustness of mutualistic networks under phenological change and habitat destruction. Oikos , 124 (1), 22-32.

Sayers, T. D., Steinbauer, M. J., \& Miller, R. E. (2019). Visitor or vector? The extent of rove beetle (Coleoptera: Staphylinidae) pollination and floral interactions. Arthropod-Plant Interactions , 13 (5), 685-701.

Slaviero, A., Del Vecchio, S., Pierce, S., Fantinato, E., \& Buffa, G. (2016). Plant community attributes affect dry grassland orchid establishment. Plant Ecology , 217 (12), 1533-1543.

Spiesman, B. J., \& Inouye, B. D. (2013). Habitat loss alters the architecture of plant-pollinator interaction networks. Ecology , 94 (12), 2688-2696.

Taylor, L. R. (1963). Analysis of the effect of temperature on insects in flight. The Journal of Animal Ecology , 99-117.

Thayer, M. K., des Tierreiches, E. N. D. S., Kristensen, N. P., \& Beutel, R. G. (2003). 11.7. Staphylinidae Latreille, 1802. tic .

Thebault, E., \& Fontaine, C. (2010). Stability of ecological communities and the architecture of mutualistic and trophic networks. Science, 329 (5993), 853-856.

Traveset, A., Tur, C., \& Eguiluz, V. M. (2017). Plant survival and keystone pollinator species in stochastic coextinction models: role of intrinsic dependence on animal-pollination. Scientific reports , 7 (1), $1-10$.

Traveset, A., Castro-Urgal, R., Rotllan-Puig, X., \& Lazaro, A.(2018). Effects of habitat loss on the plant-flower visitor network structure of a dune community. Oikos , 127 (1), 45-55.

Tur, C., Castro-Urgal, R., \& Traveset, A. (2013). Linking plant specialization to dependence in interactions for seed set in pollination networks. PloS one , 8 (10), e78294.

Tylianakis, J. M. (2013). The global plight of pollinators. Science, 339 (6127), 1532-1533.

Vanbergen, A. J., Woodcock, B. A., Gray, A., Grant, F., Telford, A., Lambdon, P., ... \&

Cavers, S. (2014). Grazing alters insect visitation networks and plant mating systems. Functional ecology 
, 28 (1), 178-189.

Van der Maarel, E., \& van der Maarel-Versluys, M. (1996). Distribution and conservation status of littoral vascular plant species along the European coasts. Journal of Coastal Conservation , 2 (1), 73-92.

Waser, N. M. (1978). Competition for hummingbird pollination and sequential flowering in two Colorado wildflowers. Ecology, 59 (5), 934-944.

Waser, N. M., \& Real, L. A. (1979). Effective mutualism between sequentially flowering plant species. Nature, 281 (5733), 670-672.

Westrich, P. (2001). Zum pollensammelverhalten der seidenbiene Colletes floralis eversmann 1852 (Hymenoptera, Apidae).

Welti, E. A., \& Joern, A. (2018). Fire and grazing modulate the structure and resistance of plant-floral visitor networks in a tallgrass prairie. Oecologia , 186 (2), 517-528.

Wojcik, V. A., Morandin, L. A., Davies Adams, L., \& Rourke, K. E. (2018). Floral resource competition between honey bees and wild bees: is there clear evidence and can we guide management and conservation?. Environmental entomology , 47 (4), 822-833.

Zanella, L., Uliana, M., Scarton, F., Barbieri, F., \& Ratti, E. (2009). Valutazione ambientale di alcuni arenili veneti con formazioni a dune mediante lo studio della coleotterofauna specializzata (Insecta, Coleoptera). Bollettino Museo civico Storia naturale Venezia , 60 , 41-88.

Zych, M., Junker, R. R., Nepi, M., Stpiczyńska, M., Stolarska, B., \& Roguz, K. (2019). Spatiotemporal variation in the pollination systems of a supergeneralist plant: is Angelica sylvestris (Apiaceae) locally adapted to its most effective pollinators?. Annals of botany , 123 (2), 415-428.

\section{FIGURES AND TABLES}

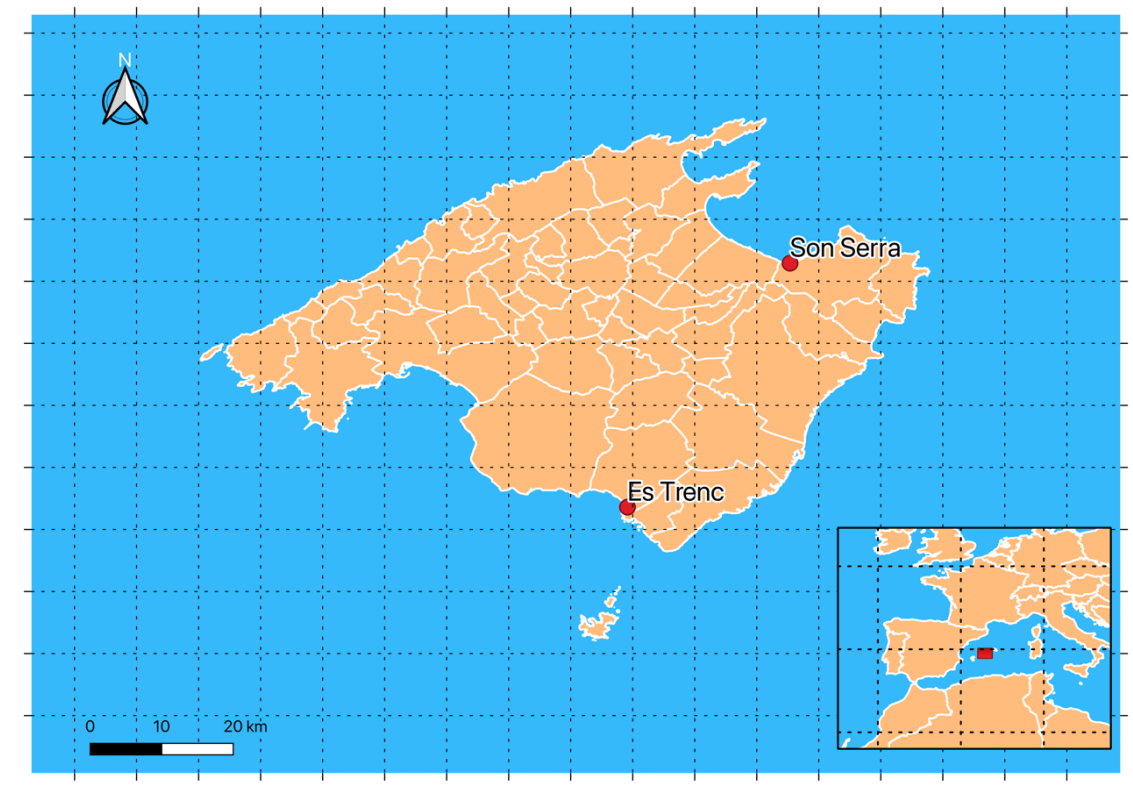

Figure 1. Map of the studied areas. Red points indicated the sampling areas, each one divided in 3 transects of $50 \mathrm{~m}$ separated by $100 \mathrm{~m}$. Main grid indicates $1 \mathrm{x} 1 \mathrm{~km}$ areas, while in secondary map 100x100 km are used. 
Figure 2. Pollinator networks of the studied populations (left $=$ Son Serra, right $=$ Es Trenc). Bow width indicates the number of interactions per box. All observed taxons, although some with no interactions, are indicated in both plots to facilitate comparison. For pollinators, genuses are indicated because species are so numerous that decreases readability (See Table S1 for complete results). Figure 3. Family (left) and Order (right) pollinator network considering both populations. Figure 4. Proportions of species in the different categories of selectivity at each of the study sites. The degree of selectivity is calculated based on the Specificity index (highly selective, Spec $>0.75$; selective, $0.75>$ Spec $>0.5$; opportunistic, $0.5>$ Spec $>0.25$; highly opportunistic, Spec $<0.25)$. Figure 5. Results of the phenological survey of 10 dune species. Colour gradient is used to indicate the flowering peaks. Figure 6. Results of the focal observation of pollinators behaviour on E. maritimum individuals. For comparison, species have been grouped in families. Table 1. Network metrics of the different populations (Son serra - SS, Es Trenc - ET) and both (All). NS= Number of pollinator species, $\mathrm{NP}=$ Number of plant species, $\mathrm{H} 2=$ Network specialization, $C=$ Connectance, $S=$ Shannon Diversity Index, $N=$ Nestedness, $L S=$ Links per Species, $N C=$ Number of Compartments, $\mathrm{NODF}=$ Nestedness based on Overlap, $V=$ Vulnerability. The significance of observed results was tested by constructing 1000 randomized networks with identical margin totals as the empirical networks and comparing the observed and random values using the null model 'r $2 \mathrm{~d}$ ' $\left({ }^{*} \mathrm{P}<0.05\right)$.

\begin{tabular}{lllllllllll}
\hline Population & $N S$ & $N P$ & $H 2$ & $C$ & $S$ & $N$ & $L S$ & $N C$ & $N O D F$ & $V$ \\
All & 82 & 18 & $0.20^{*}$ & $0.12^{*}$ & $4.88^{*}$ & $8.25^{*}$ & $1.53^{*}$ & $2^{*}$ & $33.05^{*}$ & $3.16^{*}$ \\
Es Trenc & 47 & 8 & 0.23 & 0.19 & 3.97 & 26.43 & 1.13 & 2 & 16.42 & 1.83 \\
Son Serra & 54 & 16 & $0.12^{*}$ & $0.14^{*}$ & $4.57^{*}$ & $11.83^{*}$ & $1.56^{*}$ & 1 & $33.72^{*}$ & $3.35^{*}$ \\
\hline
\end{tabular}

\section{SUPPLEMENTARY FILES}

Table S1 . List of the pollinator taxons observed per population

\begin{tabular}{|c|c|c|c|c|c|}
\hline Order & Family & Genus & Species & Es_trenc & Son_Serra \\
\hline \multirow[t]{16}{*}{ Coleoptera } & & & & 1 & 1 \\
\hline & Bruchidae & & & 1 & 0 \\
\hline & & Bruchidius & & 1 & 0 \\
\hline & Buprestidae & & & 1 & 0 \\
\hline & & Acmaeodera & & 1 & 0 \\
\hline & & & $\begin{array}{l}\text { Acmaeodera } \\
\text { convolvuii } \\
\text { J.Waltl }\end{array}$ & 1 & 0 \\
\hline & & Anthaxia & & 1 & 0 \\
\hline & & & $\begin{array}{l}\text { Anthaxia } \\
\text { umbellatarum } \\
\text { (Fabrizius, } \\
1787 \text { ) }\end{array}$ & 1 & 0 \\
\hline & Coccinellidae & & & 1 & 1 \\
\hline & & Coccinella & & 1 & 1 \\
\hline & & & $\begin{array}{l}\text { Coccinella } \\
\text { septempunc- } \\
\text { tata L. } \\
(1758)\end{array}$ & 1 & 1 \\
\hline & & Exochomus & & 1 & 0 \\
\hline & Mordellidae & & & 1 & 0 \\
\hline & & Mordellistena & & 1 & 0 \\
\hline & Oedemerinae & & & 0 & 1 \\
\hline & & Oedemera & & 0 & 1 \\
\hline
\end{tabular}




\begin{tabular}{|c|c|c|c|c|c|}
\hline Order & Family & Genus & Species & Es_trenc & Son_Serra \\
\hline & & & $\begin{array}{l}\text { Oedemera } \\
\text { flavipes } \\
\text { (Fabricius, } \\
1758 \text { ) }\end{array}$ & 0 & 1 \\
\hline & Pentatomidae & & & 1 & 0 \\
\hline & & Graphosoma & & 1 & 0 \\
\hline & & & $\begin{array}{l}\text { Graphosoma } \\
\text { lineatum } \\
\text { (Müller, 1766) }\end{array}$ & 1 & 0 \\
\hline & Scarabaeidae & & & 0 & 1 \\
\hline & & Oxythyrea & & 0 & 1 \\
\hline & & & $\begin{array}{l}\text { Oxythyrea } \\
\text { funesta (Poda, } \\
1761 \text { ) }\end{array}$ & 0 & 1 \\
\hline & & Tropinota & & 0 & 1 \\
\hline & & & $\begin{array}{l}\text { Tropinota } \\
\text { squalida } \\
\text { (Scopoli, 1783) }\end{array}$ & 0 & 1 \\
\hline & Scraptiidae & & & 1 & 0 \\
\hline & & Anaspis & & 1 & 0 \\
\hline & Tenebrionidae & & & 0 & 1 \\
\hline & & Pimelia & & 0 & 1 \\
\hline & & & $\begin{array}{l}\text { Pimelia cribra } \\
\text { (Solier, 1836) }\end{array}$ & 0 & 1 \\
\hline \multirow[t]{16}{*}{ Diptera } & & & & 1 & 1 \\
\hline & Asilidae & & & 1 & 0 \\
\hline & & Machimus & & 1 & 0 \\
\hline & Bombyllidae & & & 1 & 1 \\
\hline & & Exoprosopa & & 1 & 1 \\
\hline & & & $\begin{array}{l}\text { Exoprosopa } \\
\text { italica (Rossi, } \\
\text { 1794) }\end{array}$ & 1 & 1 \\
\hline & & Petrorossia & & 1 & 0 \\
\hline & & & $\begin{array}{l}\text { Petrorossia } \\
\text { hespera (Rossi, } \\
1790 \text { ) }\end{array}$ & 1 & 0 \\
\hline & Calliphoridae & & & 1 & 1 \\
\hline & & Lucilia & & 1 & 0 \\
\hline & & & $\begin{array}{l}\text { Lucilia Sericata } \\
\text { (Meigen, } 1826 \text { ) }\end{array}$ & 1 & 0 \\
\hline & & & $\begin{array}{l}\text { Lucilia Silvarum } \\
\text { (Meigen, 1826) }\end{array}$ & 1 & 0 \\
\hline & & Stomorhina & & 1 & 1 \\
\hline & & & $\begin{array}{l}\text { Stomorhina } \\
\text { lunata } \\
\text { (Fabricius, 1805) }\end{array}$ & 1 & 1 \\
\hline & Cloropidae & & & 1 & 0 \\
\hline & & Thaumatomyia & & 1 & 0 \\
\hline
\end{tabular}




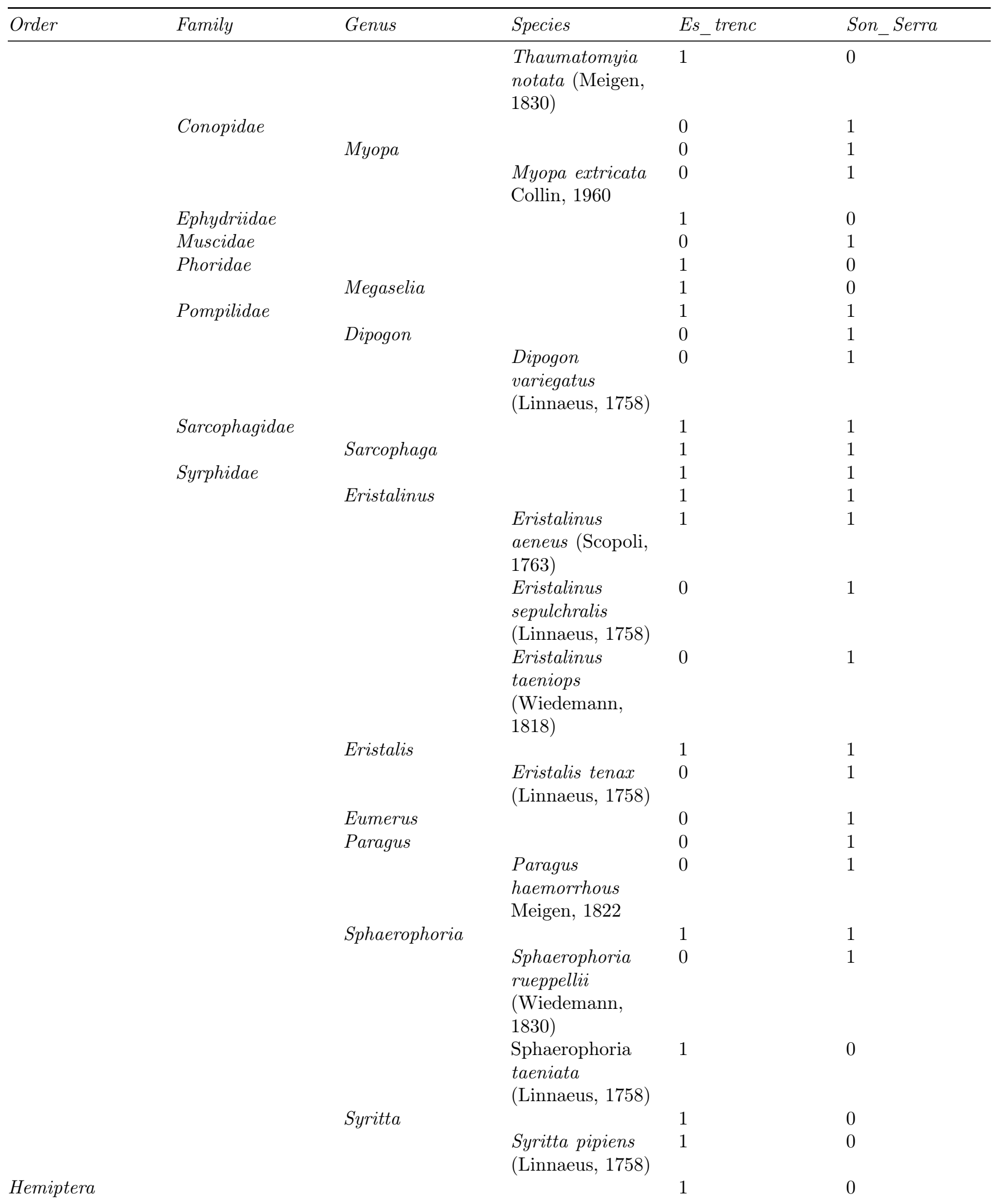




\begin{tabular}{|c|c|c|c|c|c|}
\hline Order & Family & Genus & Species & Es_trenc & Son_Serra \\
\hline & Lygaeidae & & & 1 & 0 \\
\hline & & Oxycarenus & & 1 & 0 \\
\hline & & & Oxycarenus & 1 & 0 \\
\hline & & & lavaterae & & \\
\hline & & & (Fabricius, 1787) & & \\
\hline \multirow[t]{42}{*}{ Hymenoptera } & & & & 1 & 1 \\
\hline & Andrenidae & & & 1 & 1 \\
\hline & & Andrena & & 1 & 1 \\
\hline & & & Andrena & 0 & 1 \\
\hline & & & agilissima & & \\
\hline & & & (Scopoli, 1770) & & \\
\hline & & & Andrena flavipes & 1 & 0 \\
\hline & & & Panzer, 1799 & & \\
\hline & & & Andrena morrio & 1 & 1 \\
\hline & & & Brullé, 1832 & & \\
\hline & Apidae & & & 1 & 1 \\
\hline & & Amegilla & & 1 & 1 \\
\hline & & & Amegilla & 1 & 0 \\
\hline & & & albigena & & \\
\hline & & & $\begin{array}{l}\text { (Lepeletier, } \\
1841 \text { ) }\end{array}$ & & \\
\hline & & & Amegilla & 0 & 1 \\
\hline & & & $\begin{array}{l}\text { quadrifasciata } \\
\text { (de Villers, 1789) }\end{array}$ & & \\
\hline & & Antophora & & 0 & 1 \\
\hline & & Apis & & 1 & 1 \\
\hline & & & Apis mellifera & 1 & 1 \\
\hline & & & Linnaeus, 1758 & & \\
\hline & & Bombus & & 0 & 1 \\
\hline & & & Bombus & 0 & 1 \\
\hline & & & terrestris & & \\
\hline & & & Linnaeus, 1758 & & \\
\hline & & Ceratina & & 1 & 0 \\
\hline & & & Ceratina & 1 & 0 \\
\hline & & & cucurbitina & & \\
\hline & & & (Rossi, 1792) & & \\
\hline & & Megachile & & 0 & 1 \\
\hline & & Melecta & & 0 & 1 \\
\hline & & & Melecta luctuosa & 0 & 1 \\
\hline & & & (Scopoli, 1770) & & \\
\hline & & Nomada & & 1 & 0 \\
\hline & & & Nomada succinta & 1 & 0 \\
\hline & & & Panzer, 1798 & & \\
\hline & & Pseudapis & & 1 & 0 \\
\hline & & & Pseudapis & 1 & 0 \\
\hline & & & bispinosa & & \\
\hline & & & (Brullé, 1832) & & \\
\hline & & Thyreus & & 0 & 1 \\
\hline & & Xylocopa & & 0 & 1 \\
\hline
\end{tabular}




\begin{tabular}{|c|c|c|c|c|c|}
\hline Order & Family & Genus & Species & Es_trenc & Son_Serra \\
\hline & & & $\begin{array}{l}\text { Xylocopa } \\
\text { violacea } \\
\text { (Linnaeus, 1758) }\end{array}$ & 0 & 1 \\
\hline & \multirow[t]{10}{*}{ Cabronidae } & & & 1 & 1 \\
\hline & & Cerceris & & 1 & 0 \\
\hline & & & $\begin{array}{l}\text { Cerceris } \\
\text { arenaria } \\
\text { (Linnaeus, 1758) }\end{array}$ & 1 & 0 \\
\hline & & & $\begin{array}{l}\text { Cerceris sabulosa } \\
\text { (Panzer, 1799) }\end{array}$ & 1 & 0 \\
\hline & & Oxybelus & & 1 & 0 \\
\hline & & Philanthus & & 1 & 1 \\
\hline & & & $\begin{array}{l}\text { Philanthus } \\
\text { triangulum } \\
\text { (Fabricius, 1775) }\end{array}$ & 1 & 1 \\
\hline & & Stizus & & 0 & 1 \\
\hline & & & $\begin{array}{l}\text { Stizus fasciatus } \\
\text { (Fabricius, 1781) }\end{array}$ & 0 & 1 \\
\hline & & Tachysphex & & 1 & 1 \\
\hline & \multirow{9}{*}{ Colletidae } & & & 1 & 1 \\
\hline & & Colletes & & 1 & 1 \\
\hline & & & $\begin{array}{l}\text { Colletes abeillei } \\
\text { (Pérez, 1903) }\end{array}$ & 1 & 1 \\
\hline & & & $\begin{array}{l}\text { Colletes } \\
\text { succintus } \\
\text { (Linnaeus, 1758) }\end{array}$ & 1 & 0 \\
\hline & & Hylaeus & & 1 & 1 \\
\hline & & & $\begin{array}{l}\text { Hylaeus } \\
\text { annularis } \\
\text { (Kirby, 1802) }\end{array}$ & 0 & 1 \\
\hline & & & $\begin{array}{l}\text { Hylaeus pictus } \\
\text { (Smith, 1853) }\end{array}$ & 1 & 1 \\
\hline & & & $\begin{array}{l}\text { Hylaeus } \\
\text { punctatus } \\
\text { (Brullé, 1832) }\end{array}$ & 1 & 0 \\
\hline & & & $\begin{array}{l}\text { Hylaeus } \\
\text { taeniolatus } \\
\text { (Förster, 1871) }\end{array}$ & 1 & 0 \\
\hline & \multirow[t]{7}{*}{ Halictidae } & & & 1 & 1 \\
\hline & & Ceylalictus & & 1 & 0 \\
\hline & & & $\begin{array}{l}\text { Ceylalictus } \\
\text { variegatus } \\
\text { (Olivier, 1789) }\end{array}$ & 1 & 0 \\
\hline & & Halictus & & 1 & 1 \\
\hline & & & $\begin{array}{l}\text { Halictus Fulvipes } \\
\text { (Klug, 1817) }\end{array}$ & 0 & 1 \\
\hline & & & $\begin{array}{l}\text { Halictus } \\
\text { scabiosae (Rossi, } \\
1790)\end{array}$ & 1 & 1 \\
\hline & & Lasioglossum & & 1 & 1 \\
\hline
\end{tabular}




\begin{tabular}{|c|c|c|c|c|c|}
\hline Order & Family & Genus & Species & Es_trenc & Son_Serra \\
\hline & & & $\begin{array}{l}\text { Lasioglossum } \\
\text { albocinctum } \\
\text { (Lucas, 1849) } \\
\text { Lasioglossum } \\
\text { nitidulum } \\
\text { (Fabricius, 1804) }\end{array}$ & 1 & 0 \\
\hline & & Sphecodes & & 0 & 1 \\
\hline & & & $\begin{array}{l}\text { Sphecodes sf. } \\
\text { ruficrus }\end{array}$ & 0 & 1 \\
\hline & Leucospidae & & & 0 & 1 \\
\hline & & Leucospis & & 0 & 1 \\
\hline & & & $\begin{array}{l}\text { Leucospis gigas } \\
\text { (Fabricius, 1793) }\end{array}$ & 0 & 1 \\
\hline & Megachilidae & & & 1 & 1 \\
\hline & & Anthidium & & 0 & 1 \\
\hline & & & $\begin{array}{l}\text { Anthidium } \\
\text { florentinum } \\
\text { (Fabricius, 1775) }\end{array}$ & 0 & 1 \\
\hline & & Chalicodoma & & 0 & 1 \\
\hline & & & $\begin{array}{l}\text { Chalicodoma } \\
\text { sicula (Rossi, } \\
1792 \text { ) }\end{array}$ & 0 & 1 \\
\hline & & Heriades & & 1 & 0 \\
\hline & & Osmia & & 1 & 0 \\
\hline & & & $\begin{array}{l}\text { Osmia aurulenta } \\
\text { (Panzer, 1799) }\end{array}$ & 1 & 0 \\
\hline & & & $\begin{array}{l}\text { Osmia latreillei } \\
\text { (Spinola, 1806) }\end{array}$ & 1 & 0 \\
\hline & & Rhodanthidium & & 1 & 1 \\
\hline & & & $\begin{array}{l}\text { Rhodanthidium } \\
\text { septemdentatum } \\
\text { (Latreille, 1809) }\end{array}$ & 1 & 1 \\
\hline & & & $\begin{array}{l}\text { Rhodanthidium } \\
\text { sticticum } \\
\text { (Fabricius, 1787) }\end{array}$ & 0 & 1 \\
\hline & Pollistidae & & & 1 & 1 \\
\hline & & Bembecinus & & 0 & 1 \\
\hline & & & $\begin{array}{l}\text { Bembecinus } \\
\text { tridens } \\
\text { (Fabricius, 1781) }\end{array}$ & 0 & 1 \\
\hline & & Pollistes & & 1 & 1 \\
\hline & & & $\begin{array}{l}\text { Pollistes } \\
\text { dominula } \\
\text { (Christ, 1791) }\end{array}$ & 1 & 1 \\
\hline & & & $\begin{array}{l}\text { Pollistes gallicus } \\
\text { (Linnaeus, 1767) }\end{array}$ & 1 & 1 \\
\hline & Pompilidae & & & 1 & 1 \\
\hline & & Entomobora & & 1 & 1 \\
\hline
\end{tabular}




\begin{tabular}{|c|c|c|c|c|c|}
\hline Order & Family & Genus & Species & Es_trenc & Son_Serra \\
\hline & & & $\begin{array}{l}\text { Entomobora } \\
\text { fuscipennis } \\
\text { (Vander Linden, } \\
1827 \text { ) }\end{array}$ & 1 & 0 \\
\hline & Scollidae & & & 1 & 1 \\
\hline & & Dasyscolia & & 0 & 1 \\
\hline & & & $\begin{array}{l}\text { Dasyscolia } \\
\text { ciliata } \\
\text { (Fabricius, 1787) }\end{array}$ & 0 & 1 \\
\hline & Scollidae & Megascolia & & 1 & 1 \\
\hline & & & $\begin{array}{l}\text { Megascolia } \\
\text { bidens } \\
\text { (Linnaeus, 1767) }\end{array}$ & 1 & 1 \\
\hline & & & $\begin{array}{l}\text { Megascolia } \\
\text { maculata } \\
\text { (Drury, 1773) }\end{array}$ & 1 & 1 \\
\hline & Sphecidae & & & 0 & 1 \\
\hline & & Sphex & & 0 & 1 \\
\hline & & & $\begin{array}{l}\text { Sphex funerarius } \\
\text { (Gussakovskij, } \\
\text { 1934) }\end{array}$ & 0 & 1 \\
\hline & Syrphidae & & & 1 & 1 \\
\hline & & Sphaerophoria & & 1 & 1 \\
\hline & Typhiidae & & & 1 & 0 \\
\hline & & Meria & & 1 & 0 \\
\hline & & & $\begin{array}{l}\text { Meria } \\
\text { tripunctata } \\
\text { (Rossi, 1790) }\end{array}$ & 1 & 0 \\
\hline & Vespidae & & & 1 & 1 \\
\hline & & Ancistrocerus & & 0 & 1 \\
\hline & & & $\begin{array}{l}\text { Ancistrocerus } \\
\text { kitcheneri } \\
\text { (Dusmet, 1917) }\end{array}$ & 0 & 1 \\
\hline & & Eumenes & & 1 & 0 \\
\hline & & & $\begin{array}{l}\text { Eumenes } \\
\text { coarctatus } \\
\text { (Linnaeus, 1758) }\end{array}$ & 1 & 0 \\
\hline \multirow[t]{8}{*}{ Lepidoptera } & & & & 1 & 1 \\
\hline & Lycaenidae & & & 1 & 1 \\
\hline & & Celastrina & & 0 & 1 \\
\hline & & & $\begin{array}{l}\text { Celastrina } \\
\text { argiolus } \\
\text { (Linnaeus, 1758) }\end{array}$ & 0 & 1 \\
\hline & & Polyommatus & & 1 & 1 \\
\hline & & & $\begin{array}{l}\text { Polyommatus } \\
\text { celina (Austaut, } \\
1879 \text { ) }\end{array}$ & 1 & 1 \\
\hline & Noctuidae & & & 0 & 1 \\
\hline & & Autographa & & 0 & 1 \\
\hline
\end{tabular}




\begin{tabular}{|c|c|c|c|c|c|}
\hline Order & Family & Genus & Species & Es_trenc & Son_Serra \\
\hline & & & $\begin{array}{l}\text { Autographa } \\
\text { gamma } \\
\text { (Linnaeus, 1758) }\end{array}$ & 0 & 1 \\
\hline & & Odice & & 0 & 1 \\
\hline & & & $\begin{array}{l}\text { Odice blandula } \\
\text { (Rambur, 1858) }\end{array}$ & 0 & 1 \\
\hline & Nymphalidae & & & 1 & 1 \\
\hline & & Vanessa & & 1 & 1 \\
\hline & & & $\begin{array}{l}\text { Vanessa atalanta } \\
\text { (Linnaeus, 1758) }\end{array}$ & 0 & 1 \\
\hline & & & $\begin{array}{l}\text { Vanessa cardui } \\
\text { (Linnaeus, 1758) }\end{array}$ & 1 & 1 \\
\hline & Pieridae & & & 1 & 1 \\
\hline & & Colias & & 1 & 1 \\
\hline & & & $\begin{array}{l}\text { Colias Crocea } \\
\text { (Geoffroy, 1785) }\end{array}$ & 1 & 1 \\
\hline & & Gonepteryx & & 0 & 1 \\
\hline & & & $\begin{array}{l}\text { Gonepteryx } \\
\text { cleopatra } \\
\text { (Linnaeus, 1767) }\end{array}$ & 0 & 1 \\
\hline & & Pieris & & 1 & 1 \\
\hline & & & $\begin{array}{l}\text { Pieris rapae } \\
\text { (Linnaeus, 1758) }\end{array}$ & 1 & 1 \\
\hline & & Pontia & & 1 & 0 \\
\hline & & & $\begin{array}{l}\text { Pontia daplidice } \\
\text { (Linaneus, 1758) }\end{array}$ & 1 & 0 \\
\hline & Satyridae & & & 0 & 1 \\
\hline & & Pararge & & 0 & 1 \\
\hline & & & $\begin{array}{l}\text { Pararge aegeria } \\
\text { (Linnaeus, } 1758)\end{array}$ & 0 & 1 \\
\hline Orthoptera & & & & 1 & 0 \\
\hline & Acrididae & & & 1 & 0 \\
\hline
\end{tabular}

Table S2 . Plant species metrics of the different populations (Son Serra, Es Trenc) And both (All). $D=$ Number of pollinators, Str $=$ Species Strength, Spec $=$ Specificity, $d^{\prime}=$ Specialization level. Selectiveness is calculated based on theSpecificity index (highly selective, Spec $>0.75$; selective, $0.75>$ Spec $>0.5$; opportunistic, $0.5>$ Spec $>0.25$; highly opportunistic, Spec $<0.25)$.

\begin{tabular}{|c|c|c|c|c|c|c|c|c|}
\hline & Es Trenc & Es Trenc & Es Trenc & Es Trenc & Son Serra & Son Serra & Son Serra & Son Serra \\
\hline Species & $D$ & Str & Spec & $d$ & $D$ & Str & $d$ & Spec \\
\hline Cakile maritima & 5 & 3,33 & 0,42 & 0,56 & 4 & 1,58 & 0,46 & 0,48 \\
\hline Calystegia soldanella & & & & & 1 & 0,1 & 0 & 1 \\
\hline Centaurea aspersa & & & & & 5 & 1,08 & 0,06 & 0,43 \\
\hline Cistus salvifolius & & & & & 4 & 1,8 & 0,35 & 0,48 \\
\hline Eryngium maritimum & 23 & 20,53 & 0,14 & 0,43 & 28 & 16,7 & 0,25 & 0,12 \\
\hline Euphorbia parallias & & & & & 3 & 2,67 & 0,89 & 0,6 \\
\hline Glaucium flavum & & & & & 2 & 1,5 & 0,82 & 0,7 \\
\hline Helichrysum stoechas & 6 & 3,87 & 0,38 & 0,39 & 11 & 4,67 & 0,24 & 0,27 \\
\hline Launaea cervicornis & & & & & 2 & 0,45 & 0,23 & 0,7 \\
\hline
\end{tabular}




\begin{tabular}{llllllllll}
\hline & Es Trenc & Es Trenc & Es Trenc & Es Trenc & Son Serra & Son Serra & Son Serra & Son Serra & Al \\
\hline Limbardia chritmoides & 1 & 1 & 1 & 1 & & & & & \\
Limonium & 6 & 3,37 & 0,38 & 0,28 & 5 & 1,68 & 0,28 & 0,43 & 1 \\
Lotus cytisoides & 4 & 2,53 & 0,48 & 0,45 & 8 & 4,55 & 0,46 & 0,33 & 11 \\
Ononis natrix & & & & & 1 & 0,1 & 0 & 1 & 1 \\
Senecio cineraria & & & & & 7 & 2,28 & 0,15 & 0,35 & 7 \\
Teucrium dunense & 8 & 5,37 & 0,32 & 0,38 & 16 & 8,83 & 0,34 & 0,21 & 17 \\
\hline
\end{tabular}

Table S3 . Pollinator species metrics of the different populations (Son Serra, Es Trenc) And both (All). $D=$ Number of pollinators, $S t r=$ Species Strength, $S p e c=$ Specificity,$d$ ' $=$ Specialization level. Selectiveness is calculated based on the Specificity index (highly selective, Spec $>0.75$; selective, $0.75>$ Spec $>0.5$; opportunistic, $0.5>$ Spec $>0.25$; highly opportunistic, Spec $<0.25)$.

\begin{tabular}{|c|c|c|c|c|c|c|c|c|}
\hline & Es Trenc & Es Trenc & Es Trenc & Es Trenc & Son Serra & Son Serra & Son Serra & Son Serra \\
\hline Species & $D$ & Str & $d$ & Spec & $D$ & Str & $d$ & Spec \\
\hline Amegilla albigena & 1 & 0,2 & 0,49 & 1 & & & & \\
\hline Amegilla quadrifasciata & & & & & 3 & 0,49 & 0,26 & 0,53 \\
\hline Ancistrocerus kitcheneri & & & & & 1 & 0,04 & 0 & 1 \\
\hline Andrena agilissima & & & & & 1 & 0,04 & 0 & 1 \\
\hline Andrena flavipes & 1 & 0,17 & 0,43 & 1 & & & & \\
\hline Andrena morrio & 1 & 0,04 & 0 & 1 & 5 & 0,83 & 0,11 & 0,37 \\
\hline Anthaxia umbellatarum & 1 & 0,04 & 0 & 1 & & & & \\
\hline Anthidium florentinum & & & & & 1 & 0,12 & 0,38 & 1 \\
\hline Apis mellifera & 3 & 0,46 & 0,19 & 0,47 & 10 & 3,11 & 0,16 & 0,18 \\
\hline Autographa gamma & & & & & 1 & 0,06 & 0,17 & 1 \\
\hline Bembecinus tridens & & & & & 1 & 0,04 & 0 & 1 \\
\hline Bombus terrestris & & & & & 5 & 0,57 & 0,06 & 0,37 \\
\hline Celastrina argiolus & & & & & 1 & 0,04 & 0 & 1 \\
\hline Ceratina cucurbitina & 1 & 0,04 & 0 & 1 & & & & \\
\hline Cerceris arenaria & 1 & 0,04 & 0 & 1 & & & & \\
\hline Cerceris sabulosa & 1 & 0,04 & 0 & 1 & & & & \\
\hline Ceylalictus variegatus & 1 & 0,04 & 0 & 1 & & & & \\
\hline Chalicodoma sicula & & & & & 1 & 0,12 & 0,38 & 1 \\
\hline Coccinella septempunctata & 1 & 0,17 & 0,43 & 1 & 1 & 0,09 & 0,28 & 1 \\
\hline Colias crocea & 1 & 0,12 & 0,34 & 1 & 1 & 0,06 & 0,17 & 1 \\
\hline Colletes abeillei & 3 & 0,62 & 0,32 & 0,47 & 2 & 0,13 & 0,06 & 0,68 \\
\hline Colletes succintus & 1 & 0,04 & 0 & 1 & & & & \\
\hline Dasyscolia ciliata & & & & & 2 & 0,1 & 0 & 0,68 \\
\hline Dipogon variegatus & & & & & 1 & 0,04 & 0 & 1 \\
\hline Entomobora fuscipennis & 1 & 0,04 & 0 & 1 & & & & \\
\hline Eristalinus aeneus & 1 & 0,12 & 0,34 & 1 & 4 & 0,44 & 0,07 & 0,44 \\
\hline Eristalinus sepulchralis & & & & & 2 & 0,15 & 0,15 & 0,68 \\
\hline Eristalis tenax & & & & & 3 & 0,27 & 0,1 & 0,53 \\
\hline Eumenes coarctatus & 1 & 0,04 & 0 & 1 & & & & \\
\hline Exoprosopa italica & 1 & 0,17 & 0,43 & 1 & 2 & 0,38 & 0,43 & 0,68 \\
\hline Gonepteryx cleopatra & & & & & 4 & 0,58 & 0,2 & 0,44 \\
\hline Graphosoma lineatum & 1 & 0,04 & 0 & 1 & & & & \\
\hline Halictus fulvipes & & & & & 1 & 0,14 & 0,42 & 1 \\
\hline Halictus scabiosae & 1 & 0,04 & 0 & 1 & 1 & 0,04 & 0 & 1 \\
\hline Hylaeus annularis & & & & & 1 & 0,12 & 0,38 & 1 \\
\hline
\end{tabular}




\begin{tabular}{|c|c|c|c|c|c|c|c|c|}
\hline & Es Trenc & Es Trenc & Es Trenc & Es Trenc & Son Serra & Son Serra & Son Serra & Son Serra \\
\hline Hylaeus pictus & 1 & 0,04 & 0 & 1 & 1 & 0,09 & 0,28 & 1 \\
\hline Lasioglossum albocinctum & & & & & 2 & 0,29 & 0,23 & 0,68 \\
\hline Lasioglossum nitidulum & 1 & 0,25 & 0,56 & 1 & & & & \\
\hline Leucospis gigas & & & & & 1 & 0,04 & 0 & 1 \\
\hline Lucilia sericata & 1 & 0,04 & 0 & 1 & & & & \\
\hline Megascolia bidens & 3 & 0,34 & 0 & 0,47 & 2 & 0,1 & 0 & 0,68 \\
\hline Megascolia maculata & 2 & 0,21 & 0,06 & 0,65 & 2 & 0,1 & 0 & 0,68 \\
\hline Melecta luctuosa & & & & & 1 & 0,04 & 0 & 1 \\
\hline Meria tripunctata & 1 & 0,04 & 0 & 1 & & & & \\
\hline Myopa extricata & & & & & 1 & 0,04 & 0 & 1 \\
\hline Nomada succinta & 1 & 0,12 & 0,34 & 1 & & & & \\
\hline Oedemera flavipes & & & & & 1 & 0,25 & 0,58 & 1 \\
\hline Osmia aurulenta & 1 & 0,25 & 0,56 & 1 & & & & \\
\hline Osmia latreillei & 1 & 1 & 1 & 1 & & & & \\
\hline Oxycarenus lavaterae & 1 & 0,04 & 0 & 1 & & & & \\
\hline Oxythyrea funesta & & & & & 5 & 0,72 & 0,15 & 0,37 \\
\hline Paragus haemorrhous & & & & & 1 & 0,25 & 0,58 & 1 \\
\hline Pararge aegeria & & & & & 1 & 0,06 & 0,17 & 1 \\
\hline Philanthus triangulum & 1 & 0,12 & 0,34 & 1 & 3 & 0,19 & 0 & 0,53 \\
\hline Pieris rapae & 1 & 0,17 & 0,43 & 1 & 2 & 0,38 & 0,43 & 0,68 \\
\hline Pollistes dominula & 1 & 0,04 & 0 & 1 & 2 & 0,24 & 0,19 & 0,68 \\
\hline Pollistes gallicus & 1 & 0,04 & 0 & 1 & 2 & 0,7 & 0,65 & 0,72 \\
\hline Polyommatus celina & 5 & 0,75 & 0,03 & 0,26 & 4 & 0,78 & 0,25 & 0,44 \\
\hline Pontia daplidice & 1 & 0,17 & 0,43 & 1 & & & & \\
\hline Pseudapis bispinosa & 2 & 0,24 & 0,09 & 0,65 & & & & \\
\hline Sphaerophoria rueppellii & & & & & 1 & 0,25 & 0,58 & 1 \\
\hline Sphaerophoria taeniata & 1 & 0,04 & 0 & 1 & & & & \\
\hline Sphex funerarius & & & & & 2 & 0,24 & 0,19 & 0,68 \\
\hline Stizus fasciatus & & & & & 1 & 0,04 & 0 & 1 \\
\hline Stomorhina lunata & & & & & 2 & 0,54 & 0,34 & 0,68 \\
\hline Syritta pipiens & 1 & 0,2 & 0,49 & 1 & & & & \\
\hline Thaumatomyia notata & 1 & 0,04 & 0 & 1 & & & & \\
\hline Tropinota squalida & & & & & 1 & 0,5 & 0,79 & 1 \\
\hline Vanessa atalanta & & & & & 1 & 0,06 & 0,17 & 1 \\
\hline Vanessa cardui & 2 & 0,32 & 0,29 & 0,65 & 2 & 0,1 & 0 & 0,68 \\
\hline Xylocopa violacea & & & & & 1 & 0,06 & 0,17 & 1 \\
\hline
\end{tabular}

Table S4 . Pollinator family metrics. $D=$ Number of pollinators, $S t r=$ Species Strength, Spec = Specificity, $d^{\prime}=$ Specialization level. Selectiveness is calculated based on the Specificity index (highly selective, Spec $>0.75$; selective, $0.75>$ Spec $>0.5$; opportunistic, $0.5>$ Spec $>0.25$; highly opportunistic, Spec $<0.25$ ).

\begin{tabular}{llllll}
\hline Species & $D$ & Str & $d$ & Spec & Specific \\
\hline Acrididae & 1 & 1.00 & 1.00 & 1.00 & Highly selective \\
Andrenidae & 5 & 0.85 & 0.13 & 0.45 & Opportunistic \\
Apidae & 11 & 4.09 & 0.16 & 0.29 & Opportunistic \\
Bombyllidae & 3 & 0.29 & 0.31 & 0.54 & Selective \\
Bruchidae & 1 & 0.01 & 0.00 & 1.00 & Highly selective \\
Buprestidae & 1 & 0.01 & 0.00 & 1.00 & Highly selective \\
Cabronidae & 3 & 0.25 & 0.10 & 0.72 & Selective
\end{tabular}




\begin{tabular}{llllll}
\hline Species & $D$ & Str & $d$ & Spec & Specific \\
\hline Calliphoridae & 2 & 0.53 & 0.23 & 0.73 & Selective \\
Cloropidae & 1 & 0.01 & 0.00 & 1.00 & Highly selective \\
Coccinellidae & 1 & 0.12 & 0.41 & 1.00 & Highly selective \\
Colletidae & 4 & 0.56 & 0.14 & 0.55 & Selective \\
Conopidae & 3 & 0.16 & 0.07 & 0.54 & Selective \\
Ephydriidae & 1 & 0.01 & 0.00 & 1.00 & Highly selective \\
Halictidae & 6 & 1.60 & 0.16 & 0.51 & Selective \\
Leucospidae & 1 & 0.01 & 0.00 & 1.00 & Highly selective \\
Lycaenidae & 6 & 0.82 & 0.08 & 0.36 & Opportunistic \\
Lygaeidae & 1 & 0.01 & 0.00 & 1.00 & Highly selective \\
Megachilidae & 2 & 1.27 & 0.75 & 0.70 & Selective \\
Mordellidae & 1 & 0.01 & 0.00 & 1.00 & Highly selective \\
Muscidae & 1 & 0.01 & 0.00 & 1.00 & Highly selective \\
Noctuidae & 1 & 0.05 & 0.28 & 1.00 & Highly selective \\
Nymphalidae & 3 & 0.22 & 0.14 & 0.58 & Selective \\
Oedemerinae & 1 & 0.25 & 0.67 & 1.00 & Highly selective \\
Pentatomidae & 1 & 0.01 & 0.00 & 1.00 & Highly selective \\
Phoridae & 1 & 0.01 & 0.00 & 1.00 & Highly selective \\
Pieridae & 8 & 0.85 & 0.11 & 0.29 & Opportunistic \\
Pollistidae & 3 & 0.75 & 0.26 & 0.61 & Selective \\
Pompilidae & 1 & 0.04 & 0.07 & 1.00 & Highly selective \\
Sarcophagidae & 1 & 0.01 & 0.00 & 1.00 & Highly selective \\
Satyridae & 1 & 0.05 & 0.28 & 1.00 & Highly selective \\
Scarabaeidae & 6 & 1.17 & 0.28 & 0.34 & Opportunistic \\
Scollidae & 3 & 0.43 & 0.18 & 0.57 & Selective \\
Scraptiidae & 1 & 0.01 & 0.00 & 1.00 & Highly selective \\
Sphecidae & 2 & 0.11 & 0.09 & 0.68 & Selective \\
Syrphidae & 6 & 1.31 & 0.16 & 0.39 & Opportunistic \\
Typhiidae & 1 & 0.01 & 0.00 & 1.00 & Highly selective \\
Vespidae & 1 & 0.04 & 0.07 & 1.00 & Highly selective \\
\hline & & & & &
\end{tabular}

Table S5 . Pollinator order metrics of the different populations. $D=$ Number of pollinators, Str $=$ Species Strength, Spec $=$ Specificity, $d^{\prime}=$ Specialization level. Selectiveness is calculated based on the Specificity index (highly selective, Spec $>0.75$; selective, $0.75>$ Spec $>0.5$; opportunistic, $0.5>$ Spec $>0.25$; highly opportunistic,Spec < 0.25).

\begin{tabular}{llllll}
\hline Species & $D$ & Str & $d$ & Spec & Specific \\
\hline Coleoptera & 6 & 1.59 & 0.22 & 0.47 & Opportunistic \\
Diptera & 9 & 2.42 & 0.07 & 0.45 & Opportunistic \\
Hemiptera & 1 & 0.01 & 0.00 & 1.00 & Highly selective \\
Hymenoptera & 15 & 10.03 & 0.05 & 0.42 & Opportunistic \\
Lepidoptera & 9 & 1.94 & 0.09 & 0.33 & Opportunistic \\
Orthoptera & 1 & 1.00 & 1.00 & 1.00 & Highly selective \\
\hline
\end{tabular}

Table S6 . Pollinator behaviour results of the focal census onE. maritimum individuals. Time spent in visits and number of visited capitula are indicated. For some species only one observation is available. 


\begin{tabular}{|c|c|c|c|c|c|}
\hline Order & Family & Genus & Species & Time (s) & Capitula \\
\hline Coleoptera & & & & & 2 \\
\hline Diptera & & & & $67 \pm 2.35$ & 1 \\
\hline Diptera & Calliphoridae & & & $2.5 \pm 0.5$ & 1 \\
\hline Diptera & Syrphidae & & & $3 \pm 0$ & 4 \\
\hline Hemiptera & & & & & 2 \\
\hline Hymenoptera & & & & $81.45 \pm 21.41$ & $3 \pm 0.48$ \\
\hline Hymenoptera & Apidae & Amegilla & $\begin{array}{l}\text { Amegilla } \\
\text { quadrifasciata }\end{array}$ & $5.5 \pm 0.5$ & 5 \\
\hline Hymenoptera & Apidae & Bombus & $\begin{array}{l}\text { Bombus } \\
\text { terrestris }\end{array}$ & $36.78 \pm 14.62$ & $5.67 \pm 2.4$ \\
\hline Hymenoptera & Apidae & Pseudapis & $\begin{array}{l}\text { Pseudapis } \\
\text { bispinosa }\end{array}$ & 30 & 2 \\
\hline Hymenoptera & Cabronidae & & & 74 & 3 \\
\hline Hymenoptera & Cabronidae & Cerceris & & 14 & 1 \\
\hline Hymenoptera & Cabronidae & Cerceris & $\begin{array}{l}\text { Cerceris } \\
\text { arenaria }\end{array}$ & 12 & 1 \\
\hline Hymenoptera & Cabronidae & Philanthus & $\begin{array}{l}\text { Philanthus } \\
\text { triangulum }\end{array}$ & $117 \pm 23$ & \\
\hline Hymenoptera & Colletidae & & & $10 \pm 4$ & $1.5 \pm 0.5$ \\
\hline Hymenoptera & Colletidae & Colletes & $\begin{array}{l}\text { Colletes } \\
\text { succintus }\end{array}$ & 14 & 2 \\
\hline Hymenoptera & Halictidae & & & 14 & 1 \\
\hline Hymenoptera & Halictidae & Ceratina & $\begin{array}{l}\text { Ceratina } \\
\text { cucurbitina }\end{array}$ & $20 \pm 14$ & 1 \\
\hline Hymenoptera & Halictidae & Halictus & $\begin{array}{l}\text { Halictus } \\
\text { scabiosae }\end{array}$ & $28.4 \pm 7.54$ & $1.2 \pm 0.2$ \\
\hline Hymenoptera & Pollistidae & & & 13 & 1 \\
\hline Hymenoptera & Pollistidae & Pollistes & $\begin{array}{l}\text { Pollistes } \\
\text { dominula }\end{array}$ & $16.67 \pm 7.69$ & 1 \\
\hline Hymenoptera & Pollistidae & Pollistes & Pollistes gallicus & 11 & 1 \\
\hline Hymenoptera & Pompilidae & Entomobora & $\begin{array}{l}\text { Entomobora } \\
\text { fuscipennis }\end{array}$ & 10 & 1 \\
\hline Hymenoptera & Scollidae & & & $197 \pm 14$ & 6 \\
\hline Hymenoptera & Scollidae & Dasyscolia & $\begin{array}{l}\text { Dasyscolia } \\
\text { ciliata }\end{array}$ & 65 & 4 \\
\hline Hymenoptera & Scollidae & Megascolia & $\begin{array}{l}\text { Megascolia } \\
\text { bidens }\end{array}$ & $32.67 \pm 9.4$ & $2.33 \pm 0.88$ \\
\hline Hymenoptera & Scollidae & Megascolia & $\begin{array}{l}\text { Megascolia } \\
\text { maculata }\end{array}$ & $32.75 \pm 9.7$ & $1.67 \pm 0.67$ \\
\hline Hymenoptera & Sphecidae & Sphex & $\begin{array}{l}\text { Sphex } \\
\text { funerarius }\end{array}$ & 20 & 3 \\
\hline \multicolumn{6}{|l|}{ Lepidoptera } \\
\hline Lepidoptera & Lycaenidae & Polyommatus & $\begin{array}{l}\text { Polyommatus } \\
\text { celina }\end{array}$ & 281 & 1 \\
\hline Lepidoptera & Nymphalidae & Vanessa & $\begin{array}{l}\text { Vanessa } \\
\text { cardui }\end{array}$ & 79 & \\
\hline
\end{tabular}

Table S7 . Climatic data of SS and ES populations. Data collection has been restricted until the end of the fruiting season in final August of 2021. This data complements the analysis of Guijarro (1986), which 
suggested that southern dunes are colder than northern Mallorcan dunes. Data source: Wunderground (Code: ISANTA224) and Balearsmeteo (Club Nautico del Sa Rapita de Campos), respectively.

\begin{tabular}{|c|c|c|c|c|c|c|c|c|c|}
\hline & $\begin{array}{l}\text { ES TRENC } \\
\text { (ES) }\end{array}$ & \multicolumn{2}{|c|}{$\begin{array}{l}\text { ES TRENC } \\
\text { (ES) }\end{array}$} & \multicolumn{2}{|c|}{$\begin{array}{l}\text { ES TRENC } \\
\text { (ES) }\end{array}$} & \multicolumn{2}{|c|}{$\begin{array}{l}\text { ES TRENC } \\
\text { (ES) }\end{array}$} & $\begin{array}{l}\text { ES TRENC } \\
\text { (ES) }\end{array}$ & $\begin{array}{l}\text { ES TRENC } \\
\text { (ES) }\end{array}$ \\
\hline & Mean $\mathrm{T}\left({ }^{\circ} \mathrm{C}\right)$ & \multicolumn{2}{|c|}{$\begin{array}{l}\text { Absolute min. } \\
\mathrm{T}\left({ }^{\mathrm{o}} \mathrm{C}\right)\end{array}$} & \multicolumn{2}{|c|}{$\begin{array}{l}\text { Mean min. } \mathrm{T} \\
\left({ }^{\mathrm{o}} \mathrm{C}\right)\end{array}$} & \multicolumn{2}{|c|}{$\begin{array}{l}\text { Absolute max. } \\
\mathrm{T}\left({ }^{\mathrm{O}} \mathrm{C}\right)\end{array}$} & $\begin{array}{l}\text { Mean max. T } \\
\left({ }^{\circ} \mathrm{C}\right)\end{array}$ & $\begin{array}{l}\text { Precipiation } \\
(\mathrm{mm})\end{array}$ \\
\hline January & 10,8 & \multicolumn{2}{|c|}{$-1,4$} & \multicolumn{2}{|c|}{6,3} & \multicolumn{2}{|c|}{19,4} & 14,5 & 29 \\
\hline February & 13,1 & \multicolumn{2}{|l|}{2,9} & \multicolumn{2}{|l|}{8,1} & \multicolumn{2}{|l|}{21,5} & 16,8 & 2 \\
\hline March & 12,7 & \multicolumn{2}{|l|}{3,6} & \multicolumn{2}{|l|}{8} & \multicolumn{2}{|l|}{21,5} & 16,8 & 47,2 \\
\hline April & 14,5 & \multicolumn{2}{|l|}{1,9} & \multicolumn{2}{|l|}{10,3} & 21,9 & & 18,1 & 8,6 \\
\hline May & 18,1 & 10,6 & & 13,9 & & 27,1 & & 21,4 & 65,2 \\
\hline June & 23,4 & 14,7 & & 18,2 & & 35 & & 27,5 & 35 \\
\hline July & 25,3 & 17,3 & & 20,6 & & 33,1 & & 29 & 0 \\
\hline August & 26,3 & 18,8 & & 21,9 & & 37,8 & & 30,6 & 10 \\
\hline & SON & $\mathrm{SON}$ & $\mathrm{SOI}$ & & $\mathrm{SON}$ & & $\mathrm{SON}$ & $\mathrm{SON}$ & \\
\hline & SERRA & SERRA & SEP & & SER & & SERRA & SERRA & \\
\hline & $\mathrm{DE}$ & $\mathrm{DE}$ & $\mathrm{DE}$ & & $\mathrm{DE}$ & & $\mathrm{DE}$ & $\mathrm{DE}$ & \\
\hline & $\begin{array}{l}\text { MARINA } \\
\text { (SS) }\end{array}$ & $\begin{array}{l}\text { MARINA } \\
\text { (SS) }\end{array}$ & $\begin{array}{l}\mathrm{MA} \\
\text { (SS) }\end{array}$ & INA & $\begin{array}{l}\text { MAI } \\
\text { (SS) }\end{array}$ & & $\begin{array}{l}\text { MARINA } \\
\text { (SS) }\end{array}$ & $\begin{array}{l}\text { MARINA } \\
\text { (SS) }\end{array}$ & \\
\hline & $\begin{array}{l}\text { Mean T } \\
\left({ }^{\mathrm{o}} \mathrm{C}\right)\end{array}$ & $\begin{array}{l}\text { Absolute } \\
\text { min. } \mathrm{T}\left({ }^{\mathrm{o}} \mathrm{C}\right)\end{array}$ & $\begin{array}{l}\text { Mea } \\
\text { T }\left({ }^{\mathrm{c}}\right.\end{array}$ & $\begin{array}{l}\text { min. } \\
\text { C) }\end{array}$ & $\begin{array}{l}\text { Absc } \\
\max \end{array}$ & $\left({ }^{\mathrm{O}} \mathrm{C}\right)$ & $\begin{array}{l}\text { Mean max. } \\
\mathrm{T}\left({ }^{\mathrm{o}} \mathrm{C}\right)\end{array}$ & $\begin{array}{l}\text { Precipiation } \\
(\mathrm{mm})\end{array}$ & $\begin{array}{l}\text { Precipiation } \\
(\mathrm{mm})\end{array}$ \\
\hline January & 10,4 & $-0,1$ & 5,8 & & 25,3 & & 15,6 & 66,97 & 66,97 \\
\hline February & 12,8 & 2,9 & 7,8 & & 25,1 & & 18,2 & 3,6 & 3,6 \\
\hline March & 12,8 & 4,5 & 7,5 & & 23,8 & & 17,5 & 40,6 & 40,6 \\
\hline April & 13,8 & 2 & 9,6 & & 23,5 & & 19 & 8,9 & 8,9 \\
\hline May & 17,2 & 15 & 13,6 & & 27,9 & & 22,8 & 51,6 & 51,6 \\
\hline June & 23,8 & 15 & 17,3 & & 34 & & 28,1 & 46,7 & 46,7 \\
\hline July & 26 & 16,6 & 20,4 & & 38,1 & & 32,1 & 8,7 & 8,7 \\
\hline August & 26,1 & 18 & 21,6 & & 40,8 & & 31,5 & 60,9 & 60,9 \\
\hline
\end{tabular}




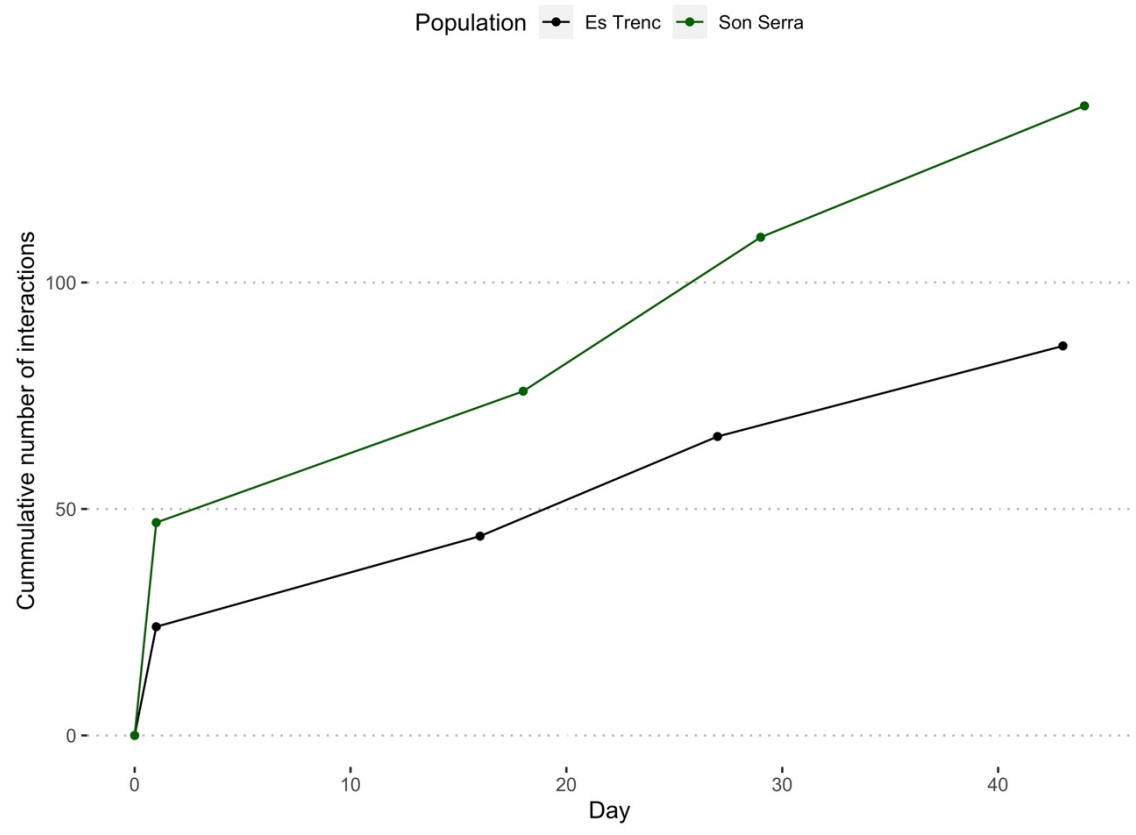

Figure S1 . Rarefaction plot of the cumulative number of new interactions per population per sampling session

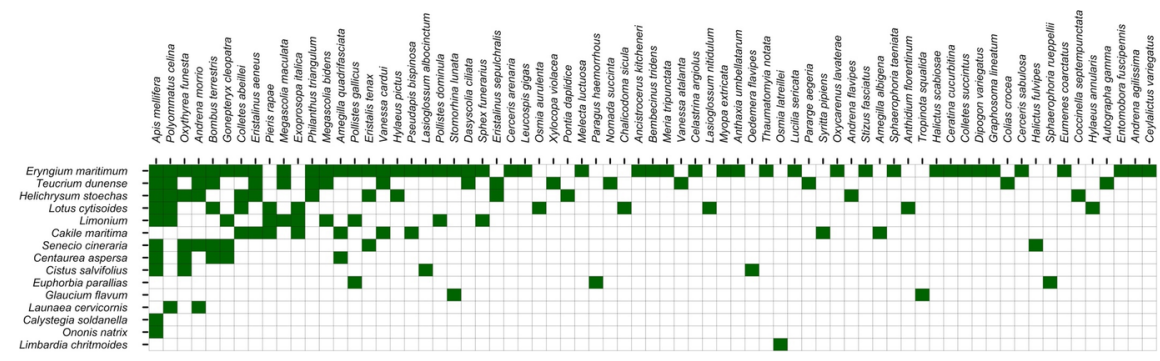

Figure S2 . Matrix of pollinators per plant species. Pollinator species are ordered by diversity of interactions (grade of selectiveness) from left to right. 

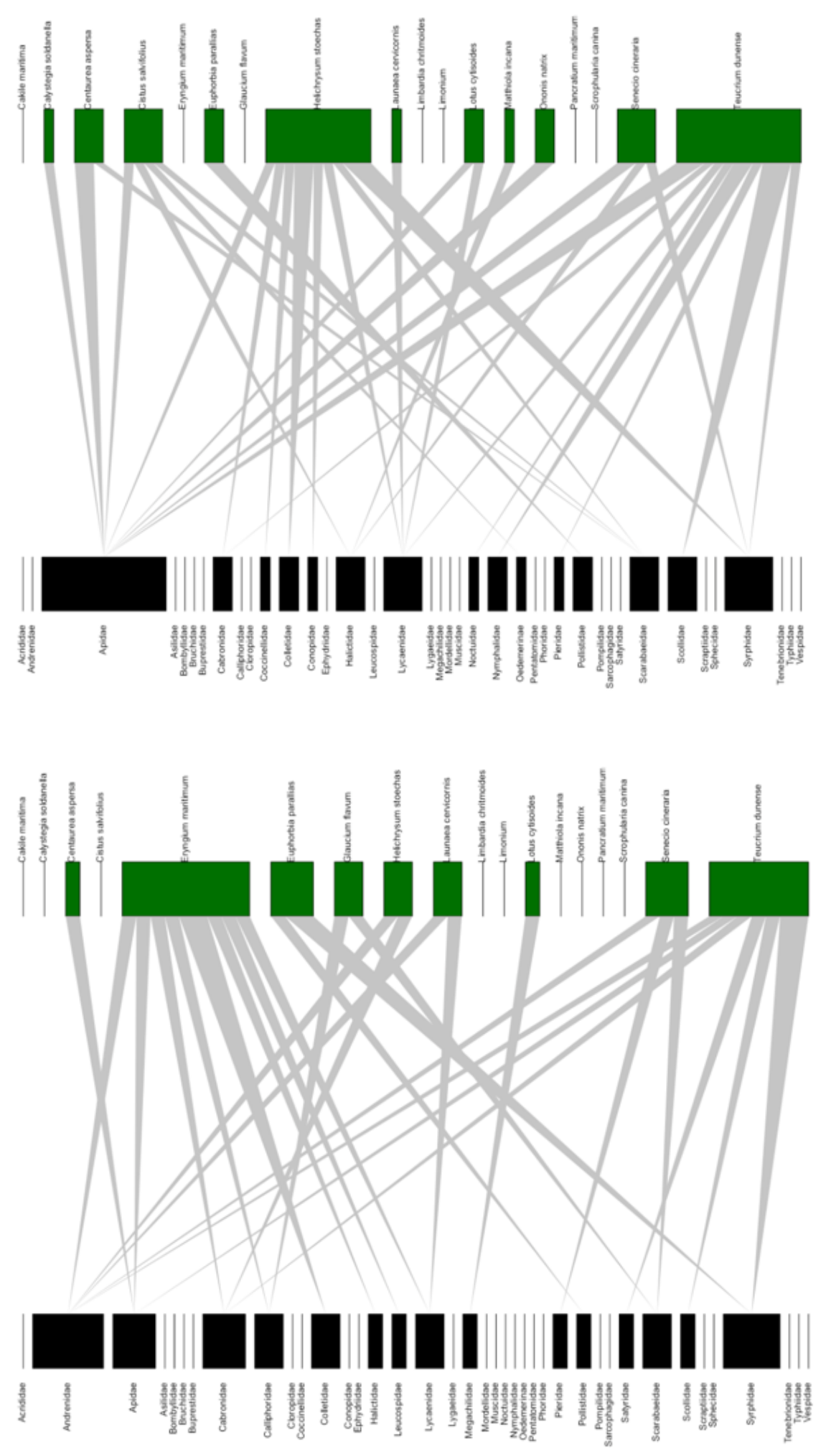

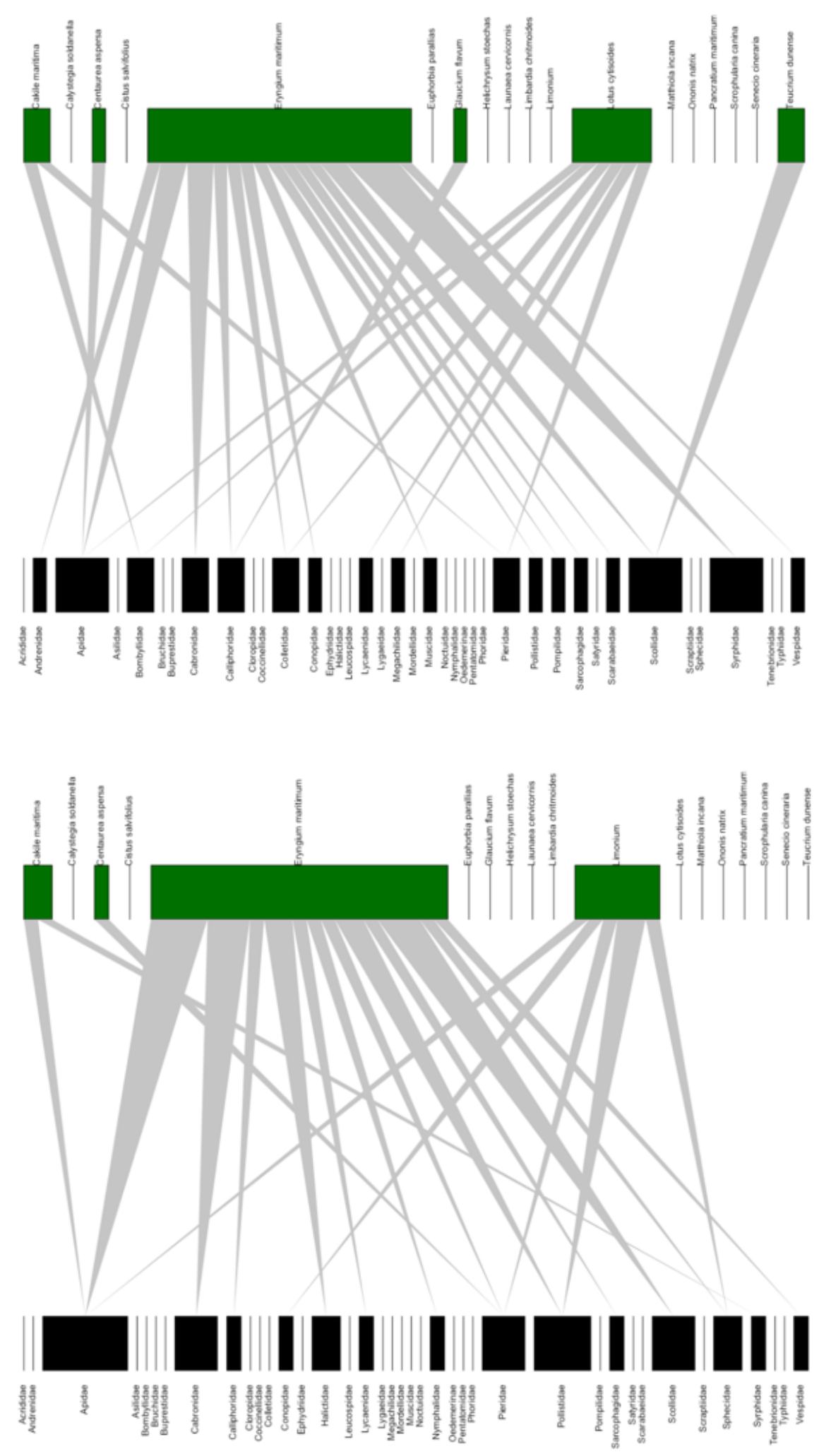

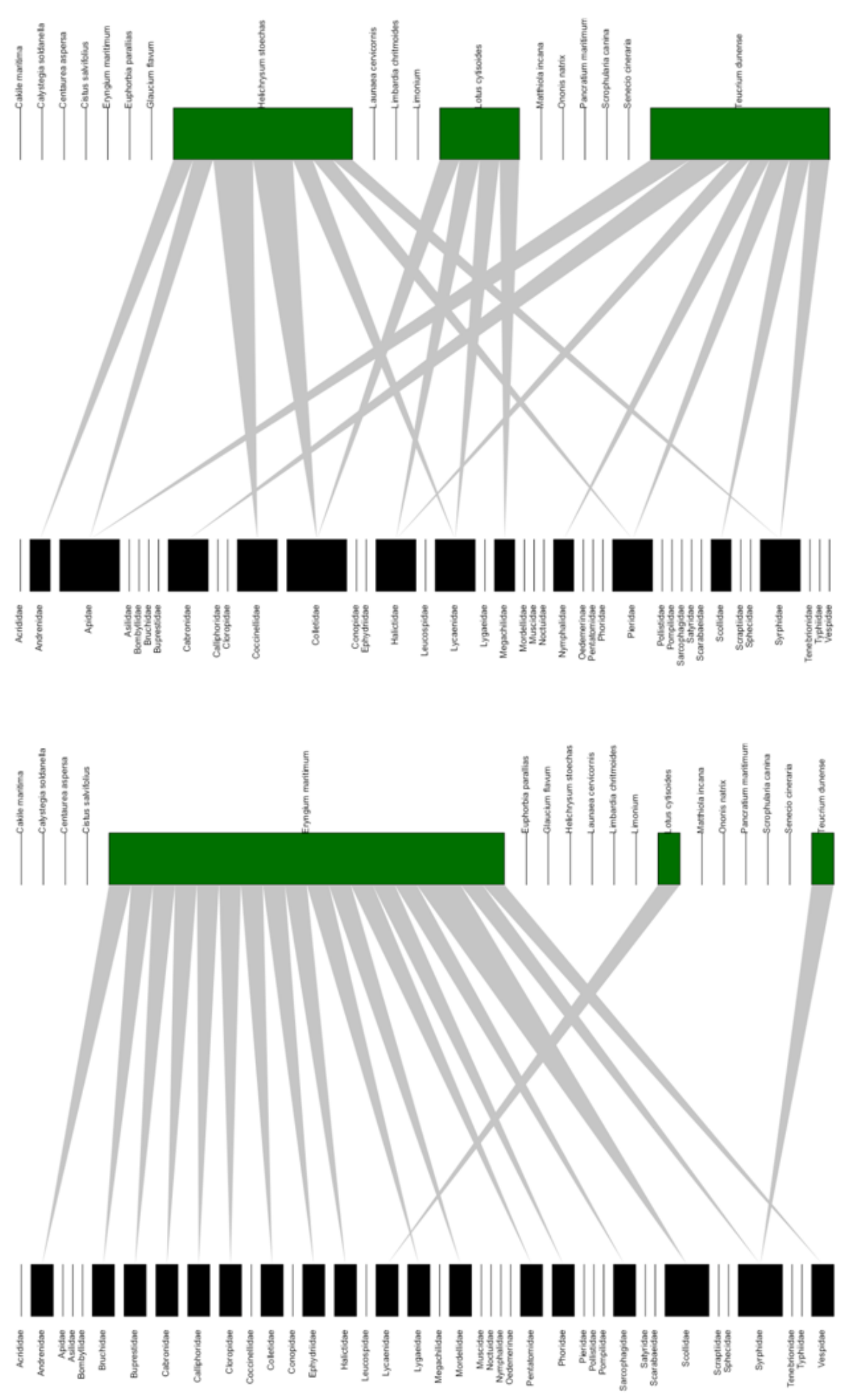

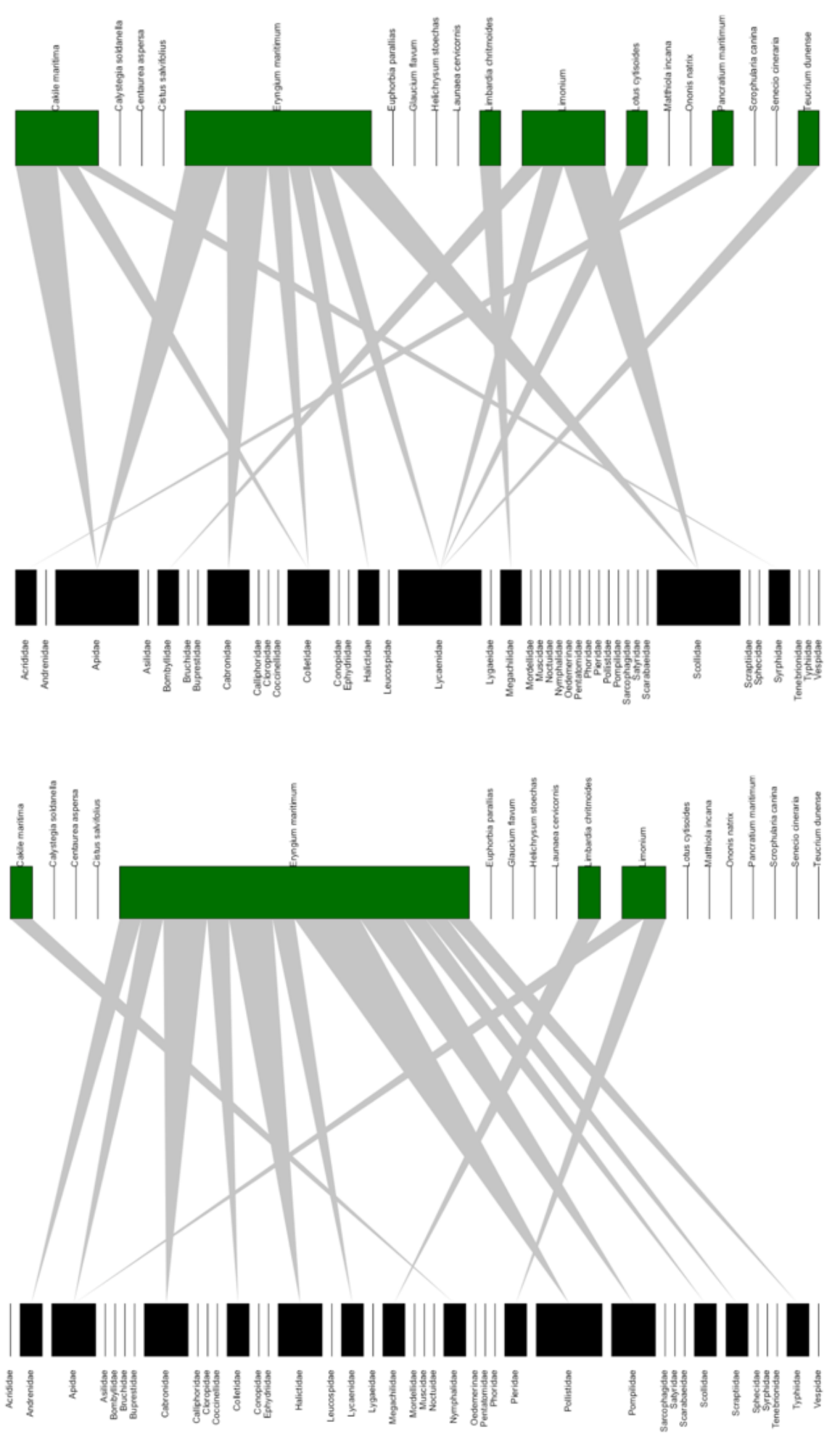

Figure S3 . Pollinator networks by day of sampling (left to right). First row indicates samples in Son Serra de Marina, while second indicates Es Trenc networks. The timing between samples between populations is one week, while between samples of the same population is two weeks. 